\title{
Bhutan: Selected Issues and Statistical Appendix
}

This Selected Issues paper and Statistical Appendix for Bhutan was prepared by a staff team of the International Monetary Fund as background documentation for the periodic consultation with the member country. It is based on the information available at the time it was completed on September 20, 2007. The views expressed in this document are those of the staff team and do not necessarily reflect the views of the government of Bhutan or the Executive Board of the IMF.

The policy of publication of staff reports and other documents by the IMF allows for the deletion of market-sensitive information.

To assist the IMF in evaluating the publication policy, reader comments are invited and may be sent by e-mail to publicationpolicy@imf.org.

Copies of this report are available to the public from

International Monetary Fund $\bullet$ Publication Services

700 19th Street, N.W. • Washington, D.C. 20431

Telephone: (202) 6237430 • Telefax: (202) 6237201

E-mail: publications@imf.org • Internet: http://www.imf.org

Price: $\$ 18.00$ a copy

\section{International Monetary Fund Washington, D.C.}





\section{INTERNATIONAL MONETARY FUND}

\section{BHUTAN}

\section{Selected Issues and Statistical Appendix}

Prepared by Hiroko Oura and Petia Topalova (both APD)

Approved by the Asia and Pacific Department

September 20, 2007

Contents

I. Managing the Macroeconomic Impact of the Hydropower Sector .................................3
A. Introduction

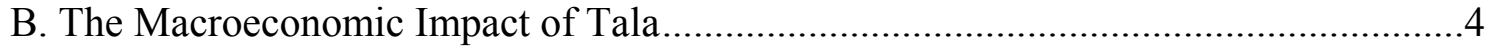
C. Financial Viability of Projects ........................................................................

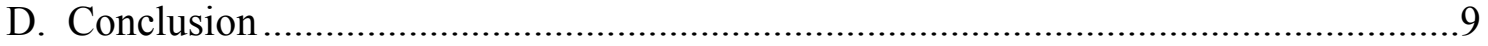

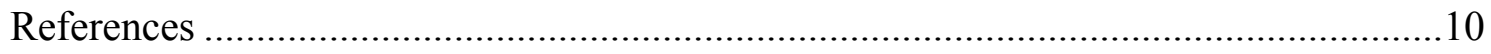

II. Rapid Private Sector Credit Growth, Macroeconomic Risks, and Financial Sector

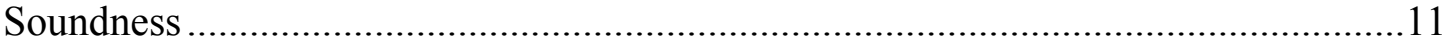

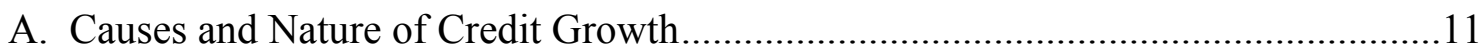

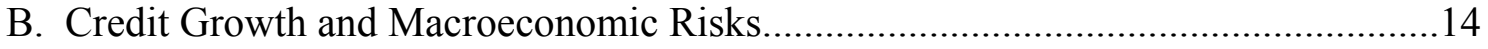

C. Credit Growth and Financial Sector Soundness ................................................... 15

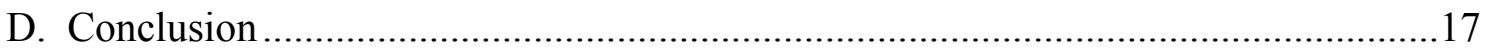

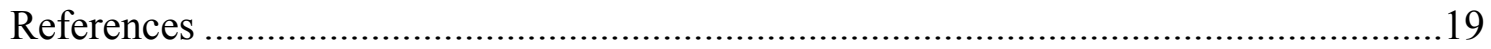

Tables

1. Gross Domestic Product by Origin at 2000 Prices, 2001-2005 ................................20

2. Gross Domestic product by Origin at Current Prices, 2001-2005 _..............................21

3. Crop Production Estimates, 2001-2005 ….................................................................22

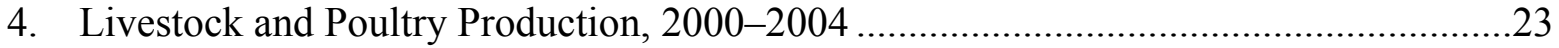

5. Logging Volume, 2001-2005 ..............................................................................24

6. Imports of Essential Food Items by the Food Corporation of Bhutan, 2001-2005 .......25

7. Gross Sales and Output of Selected Industries, 2001-2006.....................................26

8. Electricity Generation, Tariff Rates, and Trade with India, 2001/02-2005/06.............27

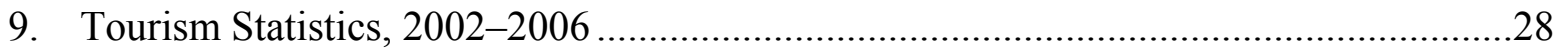

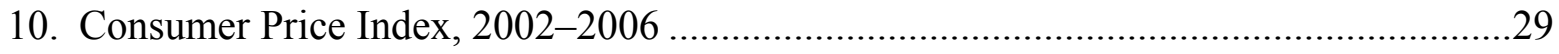




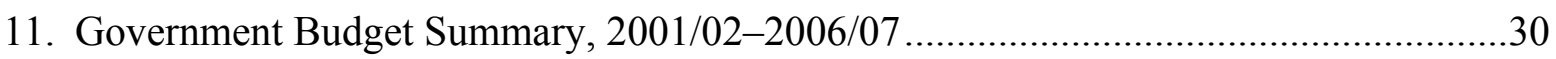

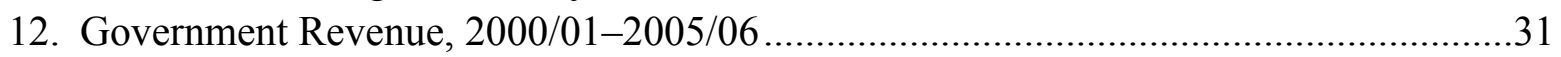

13. Economic Classification of Government Current Expenditure, 2000/01-2005/06..........32

14. Functional Classification of Government Current Expenditure, 2000/01-2005/06.........33

15. Functional Classification of Government Capital Expenditure, 2000/01-2005/06 .........34

16. Functional Classification of Total Government Expenditure, 2000/01-2005/06 ............35

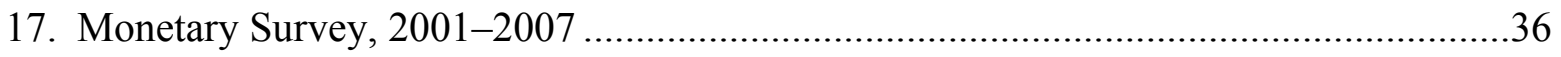

18. Assets and Liabilities of the Royal Monetary Authority of Bhutan, 2001-2007 ............37

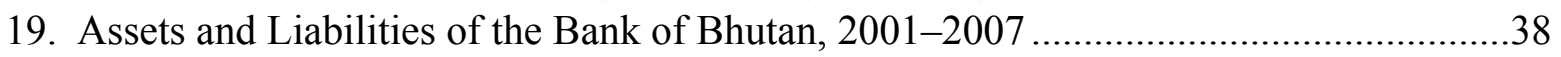

20. Assets and Liabilities of the Bhutan National Bank, 2001-2007.................................39

21. Assets and Liabilities of the Royal Insurance Corporation of Bhutan, 2001-2007 ........40

22. Assets and Liabilities of the Bhutan Development Finance Corporation, 2001-2007 ...41

23. Financial Sector Investment by Sector of Economic Activity, 2001-2006 ...................42

24. Royal Monetary Authority of Bhutan Bills Auctions, 2002-2007 ................................43

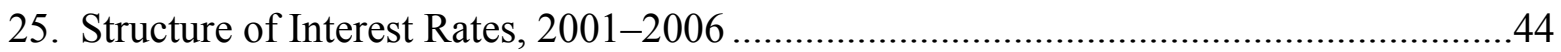

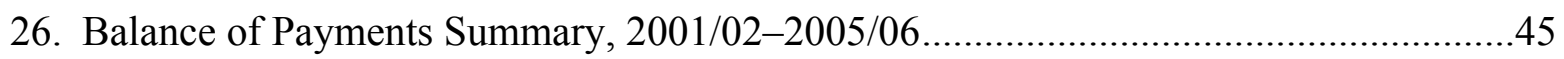

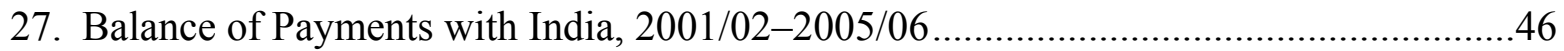

28. Balance of Payments with Third Countries, 2001/02-2005/06 .......................................4

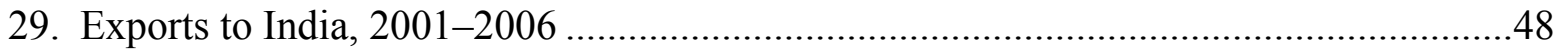

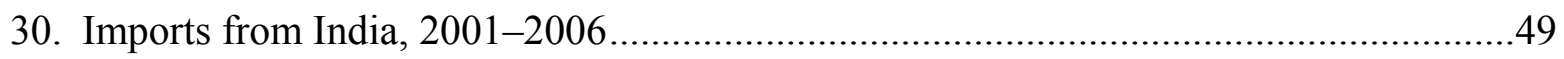

31. Exports to Third Countries, 2001-2005 ……….....................................................5

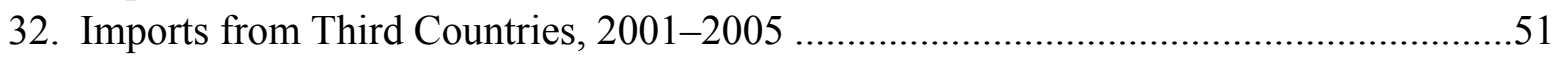

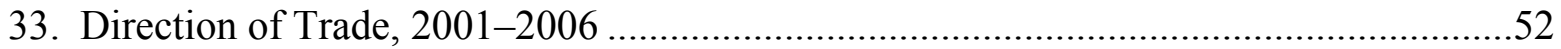

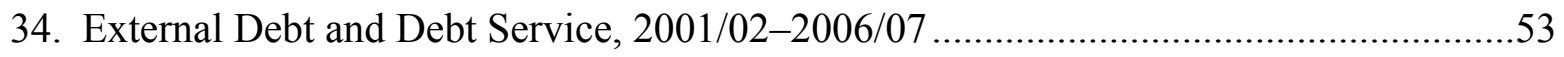

35. External Debt and Debt Service by Creditor, 2001/02-2005/06.....................................54 


\section{Managing the Macroeconomic IMPACt OF THE Hydropower SECTOR ${ }^{1}$}

\section{A. Introduction}

1. The hydropower sector in Bhutan has been growing, and a number of projects are being planned. Bhutan currently has four hydropower projects in operation (including Tala). Of these, the first major hydropower station, Chukha, came on stream in 1986. Construction of Tala hydropower station started in 1997. Upon coming on stream in 2006, Tala more than tripled Bhutan's electricity generation capacity. Looking forward, other hydropower projects are being planned. The Royal Government of Bhutan (RGB) intends to accelerate implementation of new projects to exploit its estimated 12,000 MW potential. Construction of Dagachu and Puna I projects is intended to start in 2007/08. ${ }^{2}$ Two other projects are in early stages of conception.

\begin{tabular}{|c|c|c|c|}
\hline Project & $\begin{array}{l}\text { Date of } \\
\text { Commissioning }\end{array}$ & Peak Capacity & Financing \\
\hline & & (In megawatts) & \\
\hline Chukha & 1986, 1988 & 336 & Government of India: 60 percent grant; 40 percent loan (9 percent interest) \\
\hline Kurichhu & 2001, 2002 & 60 & Government of India: 60 percent grant; 40 percent loan (10.75 percent interest) \\
\hline Basochu & 2001,2004 & 64 & $\begin{array}{l}\text { Government of Austria: } 65 \text { percent grant; } 25 \text { percent loan ( } 0.25 \text { percent interest). } \\
\text { RGoB: } 10 \text { percent }\end{array}$ \\
\hline Tala & 2006 & 1,020 & Government of India: 60 percent grant; 40 percent loan (9 percent interest) \\
\hline Dagachu & 2013 & 114 & Government of Austria, AsDB, RGoB, and possible UNDP financing \\
\hline Punachu I & 2016 & 1,095 & Government of India: 40 percent grant; 60 percent loan ( 9.5 percent interest) \\
\hline
\end{tabular}

\section{As in the past, the new projects are likely to create hydropower cycles with} ample growth dividends. Construction activities for the projects would support growth in the early years. Growth would rise significantly when the new power projects come on stream. Past projects have been successful due to a combination of factors, including political stability and prudent macroeconomic policy management; favorable relationship with India; India's high economic growth; and a large demand-supply gap in the electricity

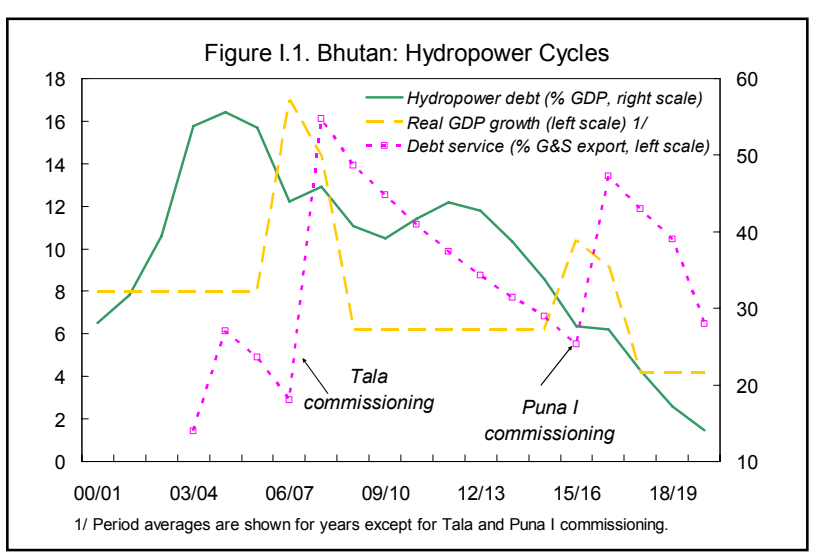

\footnotetext{
${ }^{1}$ Prepared by Hiroko Oura.

${ }^{2}$ Fiscal year starts on July 1.
} 
sector in India. Continuation of these factors and human capital accumulation in the sector from past projects bodes well for future projects.

3. This chapter discusses macroeconomic policy challenges posed by the hydropower sector. Section B discusses the macroeconomic impact of Tala, drawing on the experience of Chukha and similar projects in other countries. Section C analyzes the financial viability of the projects. Section D concludes.

\section{B. The Macroeconomic Impact of Tala}

4. The economic impact of Tala is substantial. The total construction cost at 1997 prices was 240 percent of 1997 GDP. During the construction phase, Tala supported economic growth strongly. Real GDP growth averaged 7 percent during 1997/98-2006/07. Upon commissioning, Tala tripled Bhutan's hydropower generation capacity. GDP growth is expected to jump to nearly 17 percent in 2007/08. Tala's electricity exports are projected at 11 percent of GDP; exports from existing hydropower

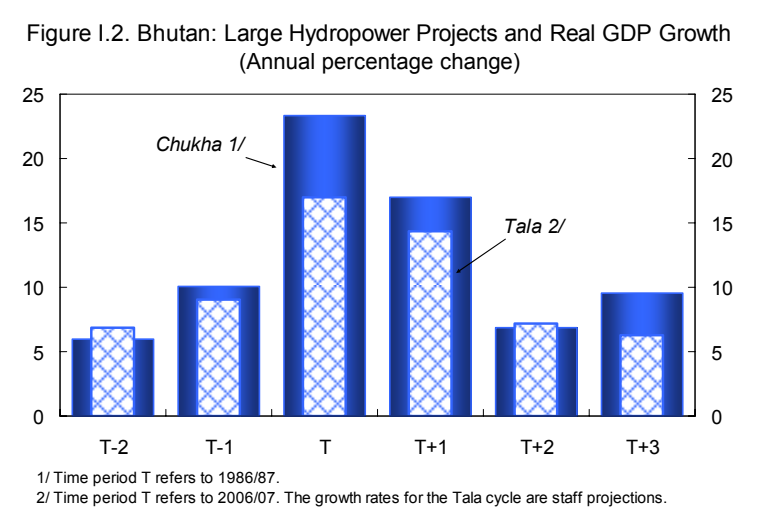
stations are about 6 percent of GDP.

5. Affordable and stable electricity supply would provide benefits to the domestic economy as well. First, cheaper energy prices can have direct disinflation effects. Second, electrification would add to productivity gains in energy-intensive manufacturing sector and enhance competitiveness in some new business areas. Third, rural electrification would increase productivity in the agricultural sector.

\section{However, a dominant, booming sector poses potential risks and policy} challenges. A potential problem posed by such a sector is the "Dutch disease" effect. These problems are particularly marked if they lead to higher budgetary spending and wage increases to government employees, potentially generating general wage and inflationary pressures. Higher domestic wages and other costs without matching productivity gains can adversely affect nonelectricity tradable goods sectors in

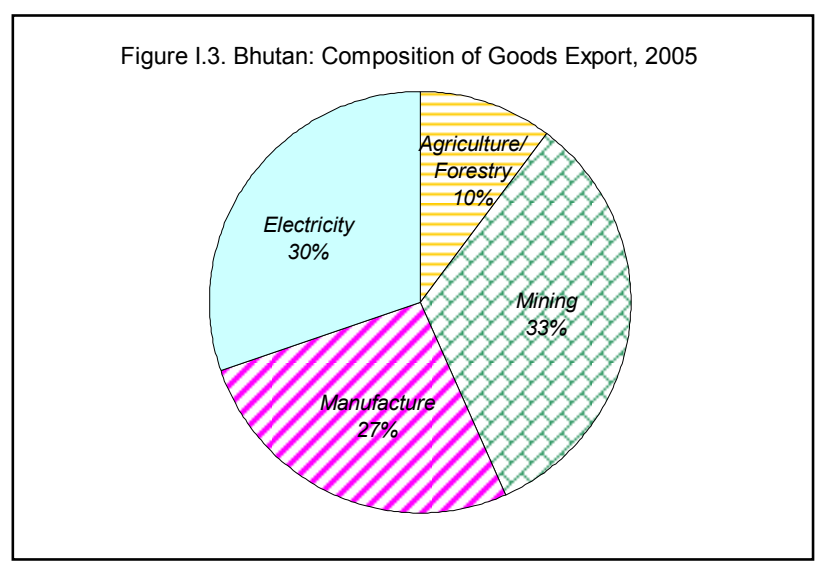


the case of Bhutan, including agriculture (vegetables, fruits, and processed food), forestry (wood products), mining, and manufacturing.

\section{Limiting "Dutch disease" effects is important for job creation and poverty}

alleviation. Despite the GDP

contribution of the hydropower and construction sectors, job creation in these sectors has been limited. ${ }^{3}$ Therefore, fostering private sector development and strengthening competitiveness in the non-hydropower sectors are critical to creating employment opportunities for a rapidly growing working age population.

Furthermore, any negative impact on

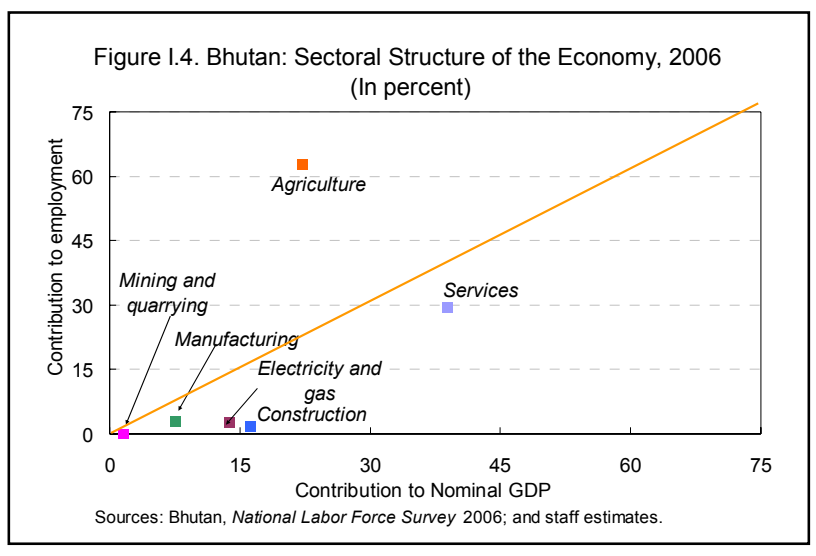
agriculture could have an adverse impact on poverty through the impact of higher inflation on real income.

\section{For Bhutan, there are potential countervailing factors at work:}

- Debt service on Tala is to start in 2007/08, limiting the net impact on the balance of payments. Annual debt service is projected at $4-6$ percent of GDP in initial years.

- $\quad$ Balance of payments and budgetary contributions from Tala would increase only gradually. Large hydropower stations often need a few years to operate at full capacity. For instance, it took almost five years after commissioning for Chukha to operate fully.

- Bhutan is dependent on international aid which could moderate over the medium term as per capita income rises.

\footnotetext{
${ }^{3}$ Construction of Tala was supported by skilled and unskilled Indian immigrant workers. It is estimated that about 90 percent of the construction spending were on Indian capital goods and labor.
} 


\section{A Comparative Perspective on Tala}

9. Bhutan showed some signs of "Dutch disease" with the Chukha power project.

- Inflation in Bhutan has generally tracked price developments in India, as about 75 percent of goods in Bhutanese CPI basket consists of tradables with India. However, the deviation from Indian CPI was noticeable in the

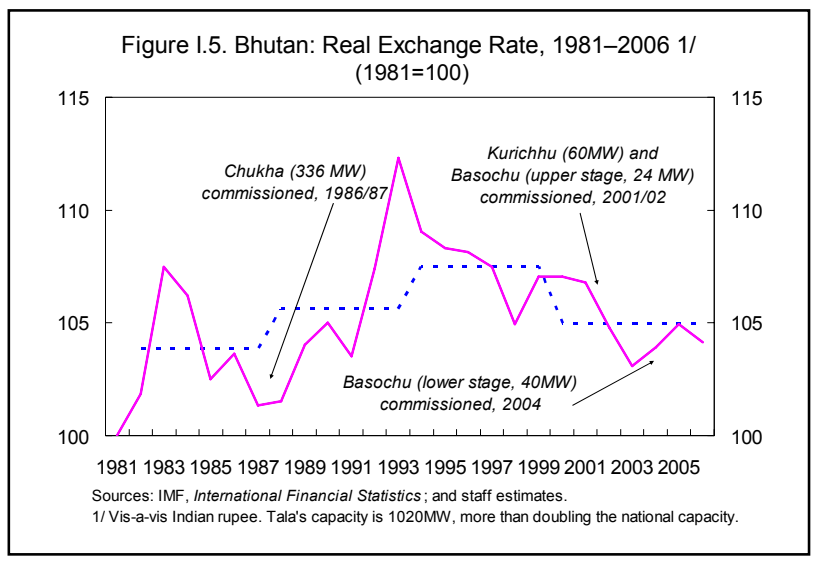
immediate years after Chukha commissioning.

- The real exchange rate vis-à-vis India appreciated after Chukha commissioning.

- $\quad$ Revenues increases from Chukha have often expanded budgetary current expenditure. For instance, the upward revision of the electricity export tariff in January 2005 was accompanied by a 45 percent increase in civil servants' wages.

- $\quad$ The growth rate in the non-hydropower tradable sectors (agriculture, mining, and manufacturing) decelerated somewhat after Chukha came on

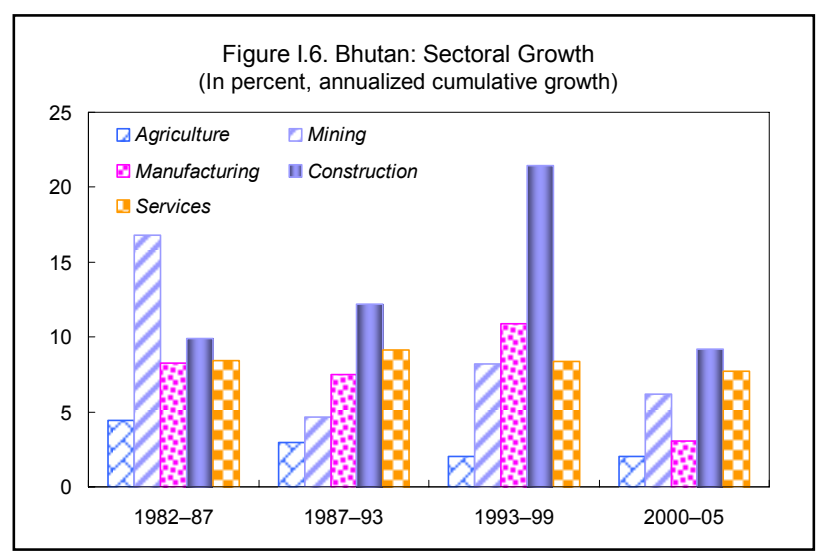
stream. On the other hand, nontradable sectors (construction and services) showed stronger growth.

10. International evidence on "Dutch disease" effects of booming sectors is mixed. Clear empirical results are hard to come by owing to difficulties with controlling for other factors that may affect the real exchange rate, sectoral structure, and growth (see Kremer (1985), Forsyth (1985), and Stijns (2003) for a discussion of Dutch and British manufacturing industries in 1970s). Cross-country studies are also not conclusive. For instance, Stijns (2003) finds that non-energy exports in oil producing countries are negatively affected after energy price booms. To the contrary, Spatafora and Warner (1999) do not find contractions in agriculture and manufacturing production for oil-producing countries in response to terms of trade shocks. In developing countries, empirical studies often find a slowdown in nonresource tradables sector growth rate in resource rich economies compared to economies without substantial natural resources (Sachs and Warner, 1995). Sala-i-Martin 
and Subramanian (2003) note that weak institutions, rent seeking and corruption, rather than Dutch disease, may be the proximate causes of such lower growth.

11. Policy measures can help limit "Dutch disease" effects. An appropriate monetary and fiscal policy mix can help contain demand pressures effectively. Some countries have directly used exchange rate policy to cope with a resource boom (for Indonesia, see Warr, 1985). Maintaining a tight fiscal stance becomes particularly important when the majority of resource revenue accrues to the government. In addition, government expenditures can be geared to productivity-enhancing investment and education/health spending rather than public consumption. Establishing revenue saving rules and investing export earnings in foreign financial assets can also help (e.g., Timor-Leste).

\section{The Itaipu hydropower project in Paraguay provides a useful comparative case} study of the potential impact of large hydropower projects (Baer and Birch, 1987; World Bank, 1992; and Valdovinos and Naranjo, 2004).

- Itaipu is the largest hydropower plant in the world with $14,000 \mathrm{MW}$ installed capacity (over 13 times of Tala). Construction on the project started in 1973; major work was completed by 1981; the project started generation in 1985; was operating at full initial capacity in 1991; and capacity was expanded in 2007. The cumulative cost at the end of 1989 was about US\$18 billion (400 percent of 1989 GDP). The project was mostly financed by external debt guaranteed by Brazil.

- The economy appears to have undergone a boom and bust cycle around the project. The direct growth and employment effects were large. During 1974-81, construction and real GDP expanded at average rate annual rates of 21 percent and 9 percent, respectively. Private sector investment rose from 10 percent of GDP in the 1960 s to 20 percent in the late 1970s. Initially, macroeconomic policies were conservative. In the early 1970 s, public saving increased and the central bank accumulated reserves. Inflation accelerated, but in line with the U.S. prices, reflecting the peg to the dollar. Credit growth averaged 13 percent. However, policies became looser at the end of the decade: credit growth picked up to over 25 percent, and domestic inflation rose. A sharp fall in foreign inflows and Itaipu construction activities in 1981, around the time of the Latin American debt crisis, triggered a recession. Moreover, private investment of the 1970s turned out to be unproductive. GDP declined by 4 percent between 1981 and 1983. Macroeconomic policies were eased, and the exchange rate peg was abandoned in 1984.

- Itaipu's experience points to some relevant factors. Full commissioning was delayed from 1988 to 1991 . Boom and bust cycles do appear to be associated with large projects. However, the impact may be hard to gauge given the long gestation periods and other complicating factors. 


\section{Financial Viability of Projects}

13. Past hydropower projects in Bhutan have been financially viable. The following table compares project costs, internal rate of return (IRR - the threshold discount rate setting NPV at zero), the net present value (NPV) of each project, and the NPV of project cash flows retained in Bhutan. The main points are:

- $\quad$ Chukha has the highest IRR, in part due to a higher export tariff rate. During the twenty years after commissioning, Chukha's tariff was raised by 37 percent in 1993, 35 percent in 1995, 100 percent in 1997, 50 percent in 1999, and 33 percent in 2005. The expected schedule for export tariff rate increases for Tala is 10 percent every five years until debt service ends and 5 percent every five years once the debt is repaid.

- $\quad$ Puna I is expected to have a smaller real cost of construction than Tala for a larger generation capacity and similar costs per unit of installed capacity to Chukha. As a result, Puna I's IRR is about 2 percentage points higher than that of Tala. However, the slower pace of tariff rate increases keeps the IRR lower (set at the same pace as Tala, lower than Chukha).

\begin{tabular}{|c|c|c|c|c|c|}
\hline \multicolumn{6}{|c|}{ Table I.2. Comparing Project Viability } \\
\hline & Installed Capacity & Total Costs 1/ & $\begin{array}{l}\text { Internal Rate } \\
\text { of Return 2/ }\end{array}$ & Project NPV 3/ & $\begin{array}{c}\text { Bhutanese Share } \\
\text { NPV 4/ }\end{array}$ \\
\hline & (In megawatts) & (In percent of GDP) & (In percent) & \multicolumn{2}{|c|}{ (In percent of GDP) } \\
\hline Chukha & 336 & 59 & 16.9 & 135 & $\ldots$ \\
\hline Tala & 1020 & 239 & 11.9 & 44 & 160 \\
\hline Punatsangchu I & 1095 & 165 & 13.7 & 169 & 144 \\
\hline \multicolumn{6}{|c|}{ Sources: Department of Energy; and IMF staff calculations. } \\
\hline \multicolumn{6}{|c|}{$\begin{array}{l}\text { 1/ In } 1997 \text { prices in percent of } 1997 \text { GDP. } \\
\text { 2/ Assuming } 10 \text { percent scrap value of total cost at the end of } 35 \text { years of commercial operation, annual operation and management cost at } \\
1.5 \text { percent of the total costs with } 4 \text { percent annual increase, } 15 \text { percent spared for domestic sales, starting export tariff for Tala at } 1.8 \text { and for } \\
\text { Puna I at expected averages tariff rate for Chukha and Tala in } 2016 \text {. }\end{array}$} \\
\hline \multicolumn{6}{|c|}{ 3/ Using 10 percent discount rate. In 1997 prices in percent of 1997 GDP. Based on total cashflows for the project. } \\
\hline
\end{tabular}

- $\quad$ The NPV of cash flows retained in Bhutan is expected to be lower for Puna I than that for Tala, reflecting the higher amount of debt in financing than Tala. A higher interest rate (10 percent) than Tala ( $9 \frac{1}{2} 2$ percent) also contributes to lower cash flows retained in Bhutan in NPV terms.

14. Furthermore, mitigating factors built into project financing limit risks. The expected project return is high enough to absorb unforeseen negative shocks. For example, with a 50 percent cost overrun for Puna I, the IRR for the project would still be over 10 percent, providing positive project NPV with a 10 percent discount rate. The same shock would knock off about 20 percent of net cash flows retained in Bhutan (in NPV terms). For large shocks, renegotiation over export tariff rates and financing conditions could take place. 
As in the case of Tala, the expectation is that cost overrun would be financed by India, using the same grant-to-debt ratio, with RGB liable for debt service.

\section{Conclusion}

15. Tala poses "Dutch disease" risks but there are countervailing factors. There could be a negative impact on growth prospects of non-hydropower sectors and on the poor through nontradable prices inflation. International experience suggests that an appropriate policy mix can help manage financial flows related to such projects. In Bhutan, as the bulk of Tala-related flows go through the government accounts, this requires an appropriate fiscal stance and skillful expenditure management. Wage increases for civil servants would need to be limited, and expenditure would need to be geared to improving infrastructure, education, and health. Expenditures on rural electrification and transportation could help raise productivity. On the monetary side, the authorities need to improve liquidity and reserves management, and ensure that excess liquidity does not generate excessive credit creation.

16. Hydropower projects in Bhutan have been financially viable, and are likely to produce significant dividends in the future as well. Tala has come on stream, despite some delays. The expected returns to Tala and Puna I are favorable. Strong ties with India are expected to mitigate project-related risks. 


\section{References}

Baer, Werner, and Melissa Birch, 1987, “The International Economic Relations of a Small Country: The Case of Paraguay," Economic Development and Cultural Change, Vol. 35 (April), pp. 601-27.

Forsyth, Peter, 1985, "Booming Sectors and Structural Change in Australia and Britain: A Comparison," in Natural Resources and the Macroeconomy, ed. by P. Neary and S. van Wijnbergen (Oxford: Blackwell).

Kremer, Jeroen, 1985, "The Dutch Disease in the Netherlands," in Natural Resources and the Macroeconomy, ed. by P. Neary and S. van Wijnbergen (Oxford: Blackwell).

Sachs, Jeffrey, and Andrew Warner, 1995, "Natural Resource Abundance and Economic Growth," in Leading Issues in Economic Development, ed. by G. Meier and J. Rauch (New York: Oxford University Press).

Sala-i-Martin, Xavier, and Arvind Subramanian, 2003, "Addressing the Natural Resource Curse: An Illustration from Nigeria," IMF Working Paper 03/139 (Washington: International Monetary Fund).

Spatafora, Nikola and Andrew Warner, 1999, "Macroeconomic and Sectoral Effects of Terms-of-Trade Shocks: The Experience of the Oil-Exporting Developing Countries,” IMF Working Paper 99/134 (Washington: International Monetary Fund).

Stijns, Jean-Philippe, 2003, "An Empirical Test of the Dutch Disease Hypothesis Using a Gravity Model of Trade," EconWPA, International Trade No. 0305001. Available via the Internet: http://ideas.repec.org/p/wpa/wuwpit/0305001.html.

Valdovinos, Carlos Fernandez, and Alexander Naranjo, 2004, "Economic Growth in Paraguay,” Economic and Social Study Series No. RE1-04-009 (Washington: Inter-American Development Bank).

Warr, Peter, 1985, “Indonesia's Other Dutch Disease: Economic Effects of the Petroleum Boom," in Natural Resources and the Macroeconomy, ed. by P. Neary and S. van Wijnbergen (Oxford: Blackwell).

World Bank, 1992, Paraguay Country Economic Memorandum, World Bank Country Study (Washington). 


\section{Rapid Private Sector Credit Growth, Macroeconomic Risks, and Financial SECTOR SOUNDNESS ${ }^{4}$}

1. This chapter reviews trends in bank lending in Bhutan, and discusses the implications of rapid credit growth for macroeconomic stability and financial sector soundness. Private sector credit growth in Bhutan has been high, averaging more than 30 percent per annum over the past seven years. While private sector credit growth and financial deepening are important underpinnings for economic growth and development (see Levine, 2005, for a survey), cross-country experience also indicates that excessively rapid credit expansion can bring substantial risks, including inflationary pressures, weakening of the current account, and financial sector vulnerabilities. Section A reviews the factors underlying rapid credit growth; Section B explores its macroeconomic implications; Section $\mathrm{C}$ focuses on the associated risks to the financial sector. Section D concludes.

\section{A. Causes and Nature of Credit Growth}

\section{Bhutan has experienced rapid} expansion of bank credit to the private sector. Over the last seven years, private sector credit increased by about 30 percent a year on average. In the previous six years, the annual growth rate was less than $4 \frac{1}{2}$ percent. With this growth, private credit as a share of GDP more than doubled from $9 \frac{1}{2}$ percent in 2001 to about 20 percent in 2007.

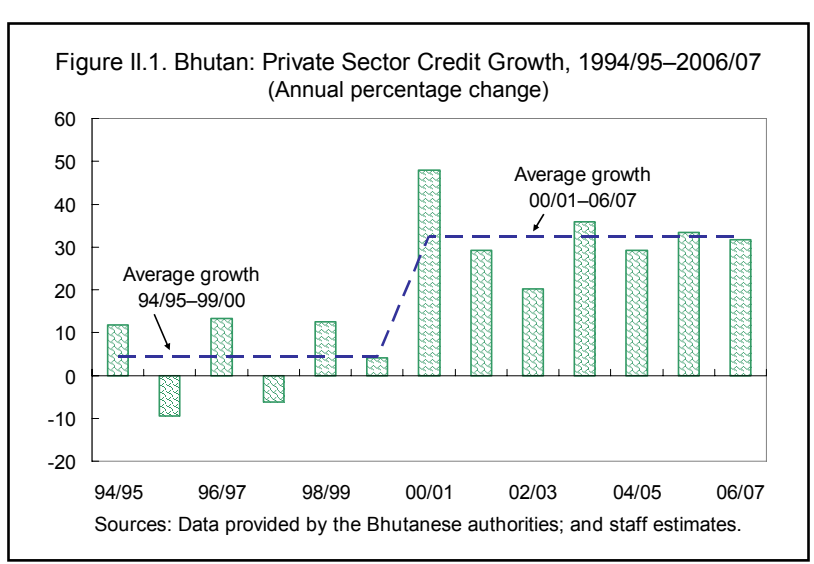

\section{Credit expansion in Bhutan was facilitated by a number of factors.}

- $\quad$ Bhutan's low initial level of financial development could partially explain the rapid growth of credit. Several studies suggest that during the early development phase of an economy, financial deepening occurs and credit growth outpaces growth in output (Levine, 1997). Even after seven years of rapid growth, credit to the private sector amounts to only

\begin{tabular}{|lcr|}
\hline \multicolumn{3}{|c|}{$\begin{array}{c}\text { Table II.1. Credit to Private Sector in } \\
\text { Cross-Country Perspective } \\
\text { (In percent of GDP) }\end{array}$} \\
\hline Country & $2001 / 02$ & $2006 / 07$ \\
\hline Bangladesh & 27.8 & 36.2 \\
Bhutan & 10.6 & 20.2 \\
Cambodia & 6.3 & 9.4 \\
India & 29.0 & 45.7 \\
Indonesia & 19.8 & 24.6 \\
Nepal & 34.1 & 36.3 \\
Vietnam & 39.3 & 71.3 \\
\hline Sources: Data provided by the Bhutanese authorities; IMF, \\
International Financial Statistics; and staff estimates. \\
\hline
\end{tabular}

\footnotetext{
${ }^{4}$ Prepared by Petia Topalova.
} 
one-fifth of GDP. When compared with other countries in the region, Bhutan remains one of the countries with the lowest level of credit to the private sector relative to the size of the economy.

- The financial sector has ample liquidity, due to large, unsterilized foreign exchange inflows from accumulated concessional loans and grants. While excess liquidity is hard to measure, the Royal Monetary Authority (RMA) estimates that as of May 2007, the banking sector had nearly $\mathrm{Nu} 7$ billion in excess reserves $\left(26 \frac{1}{2}\right.$ percent of total assets). ${ }^{5}$ This level has been maintained for the past 12 months, with a peak of $\mathrm{Nu} 7.7$ billion in January 2007. Excess reserves rose not only in levels but also as a share of banks' assets. While current accounts with the RMA

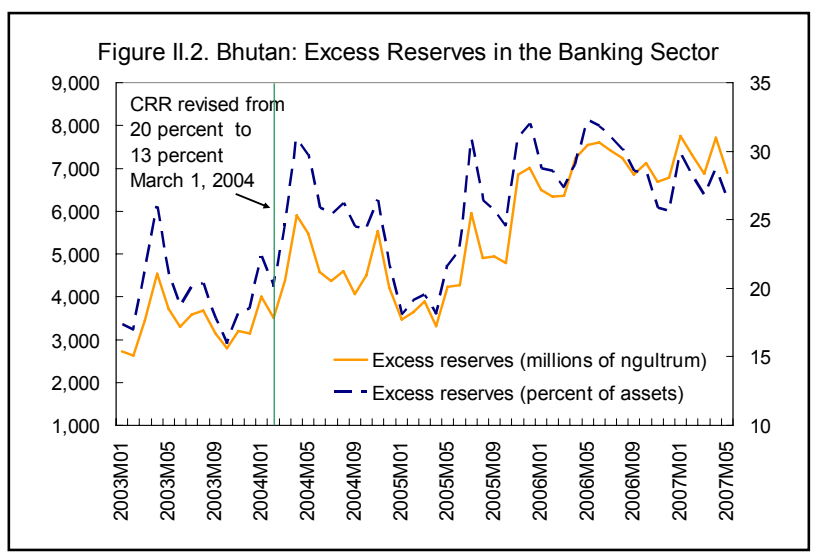
represented less than 20 percent of banks' assets in 2003, they averaged almost 30 percent of assets from January 2006 to May 2007. There is great variation in the distribution of liquidity across financial institutions. Bank of Bhutan (BOB) commands more than 97 percent of the total amount, with Bhutan National Bank (BNB) keeping almost no excess reserves.

- Monetary conditions in Bhutan have been loose relative to India. The discount rate of the RMA bills has been gradually declining from 6 percent in April 2001 to $3 \frac{1}{2}$ percent in May 2003. It has remained constant at that level since then, against a background of tightening of monetary conditions in India and the peg of the ngultrum to the Indian rupee. A reduction in the cash reserve requirement (CRR) may have contributed to the loose monetary environment. In order to spur credit growth and support investment, the RMA revised the CRR down from 20 percent to 13 percent of total deposit liabilities effective March 1, 2004, a level at which it has remained since then. The CRR was raised to 15 percent on September 1, 2007.

- The establishment of the National Pension and Provident Fund (NPPF), as an autonomous player in the financial sector, contributed to credit growth. The NPPF took over the government employment and provident fund from the Royal Insurance Corporation of Bhutan in 2002. Since then, its assets have grown at a rapid

\footnotetext{
${ }^{5}$ Excess reserves equal the financial institutions' non-interest bearing current accounts with the central bank in excess of CRR. Excess liquidity is calculated as the amount of quick assets of the financial institutions in excess of the 20 percent statutory liquidity requirement of the RMA.
} 
pace as civil servants' wages increased substantially, boosting the monthly inflow of funds and turning the NPPF into the largest institutional investor in the country. Due to limited investment opportunities, the investment mandate of the NPPF permits investments in limited financing activities, including housing (starting July 1, 2003) and education loans (starting March 1, 2004). The entry of the NPPF put substantial downward pressure on lending rates on housing loans, driving the interest rate from 13 percent to 10 percent in 2003 .

- A stable macroeconomic environment contributed to favorable economic outcomes and a demand for bank loans from households. Rising personal income growth appears to have encouraged household borrowing against current and expected future income. In particular, to respond to a substantial pent up demand, urban land use policy was revised, and a new housing policy instituted under the Urban Development Corporation in 2002. This change in policy generated an increased demand for housing loans from the banking sector skewing the sectoral composition of new credit towards a few sectors. The growth rate of credit to the building and construction sector and for personal loans has outpaced the growth of credit to other sectors in the economy by a large margin especially in the last three years. As of December 2006, 35 percent of the investments of BoB and BNB were accounted for by loans for construction and housing. In the nonbank financial institutions, the percentage of loans to these sectors is similar. Just seven years ago, the construction and housing sector comprised only 20 percent of the financial sector loan portfolio.

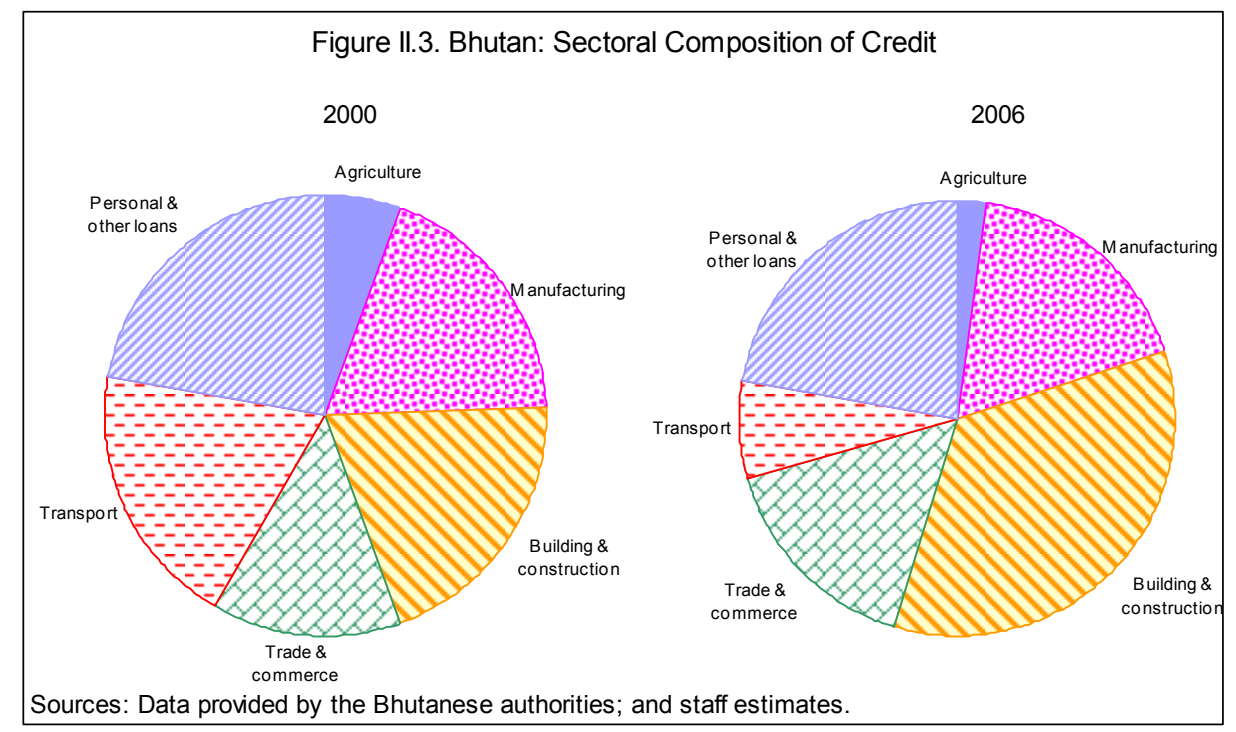


- The corporate sector contributed to the strong demand for credit as well. The establishment of special economic zones (SEZ) in southern Bhutan led to the emergence of a number of new industries, such as palm oil processing, copper processing, and ferro-alloys. In particular, five new ferro-alloy factories are under construction with financing predominantly from the domestic banking sector.

- $\quad$ Alternative investment avenues for banks are scarce. Financial instruments that could absorb excess liquidity in the financial sector are limited to RMA bills. There are no government T-bills or bonds. Both the money market and capital market are in their infancy, offering limited options for diversification.

\section{B. Credit Growth and Macroeconomic Risks}

4. Cross-country evidence suggests that while financial development is associated with faster economic growth, rapid credit growth has also been linked to substantial macroeconomic risks. Rapid credit growth can lead to overheating in the economy reflecting the surge in domestic demand, consumption and investment, thus raising the risk of inflation. The increase in domestic demand may lead to worsening in the current account from the stronger import demand and a loss of competitiveness due to a real exchange rate appreciation. Problems of reserves management may arise in the case of pegged currency, as foreign currency flows out of the country to pay for rising imports.

5. In Bhutan, despite the substantial foreign aid inflows, the buildup of excess liquidity, and the rapid credit growth, the exchange rate peg has helped anchor inflation expectations. Inflation in Bhutan has mostly followed price developments in India. Over the last seven years, inflation was contained at an average rate of 4 percent with no pronounced upward trend. While data constraints prevent the construction of a longer series of the real exchange rate, there is no evidence of a significant, sustained real appreciation of the Bhutanese currency. The real exchange rate has fluctuated within a narrow band since 2003.

\section{However, rapid credit growth affects the rupee reserve position by potentially} fueling non-hydropower related import demand. Bhutan is closely linked to the Indian economy with the ngultrum peg to the Indian rupee and free trade between the two countries. Over 75 percent of Bhutan's trade is with India; imports from India are 77 percent of total imports since 2000/01. As credit expansion accelerated, non-hydropower related import growth jumped from an average of 15 percent per annum between 1996/97 and 1999/00 to more than 20 percent per annum between 2000/01 and 2006/07. Non-hydropower related current account deficits also rose from an average of 4 percent to 13 percent of GDP over this time period. The high growth in import demand, stemming in part from the high growth in credit, for given rupee inflows in loans and grant aid from India, affects the rupee reserve position in the banks. Since January 2006, rupee reserves were at Rs. 51/4 billion (four months 
of imports from India). At end-June 2007, these reserves stood at Rs. $3 / 4$ billion ( $1 / 2$ month of imports from India).

7. The open, porous border between Bhutan and India permits exploitation of arbitrage opportunities arising from interest rate differentials. The availability of banking sector credit can facilitate this arbitrage. As noted above, the RMA bill rate has remained unchanged at $3 \frac{1}{2}$ percent since 2003, the T-bill rate in India is currently 7 percent. The rate for time deposits of less than one year at the commercial banks is $4 \frac{1}{2}$ percent; the comparable deposit rate is 7 percent in the border branches of Indian banks. Anecdotal

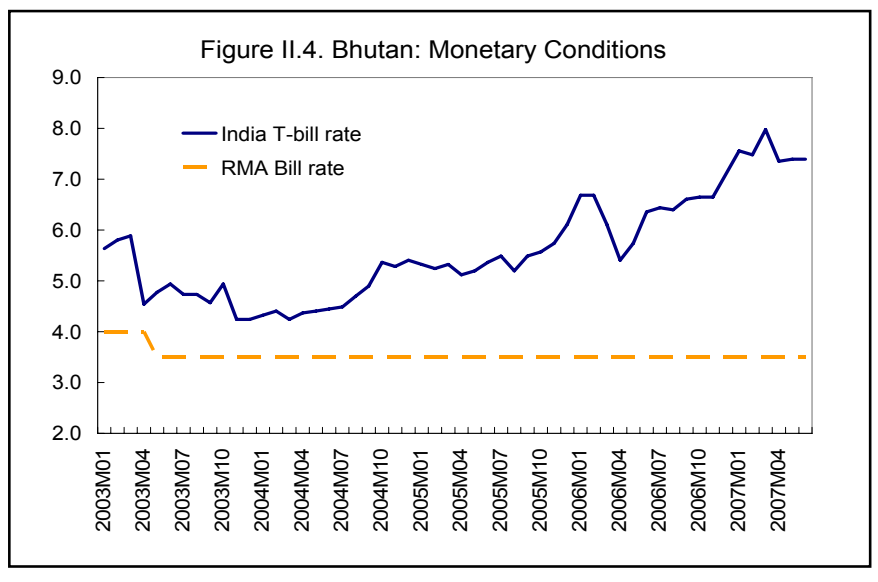
evidence suggests that these interest rate spreads may have generated some shifts in deposits from Bhutanese banks.

\section{Credit Growth and Financial Sector Soundness}

8. Rapid credit growth may also undermine financial soundness. There is a large body of literature that links credit overexpansion and banking crises (see for example IMF, 2004). This can be attributed to the procyclicality of bank lending behavior. Banks may underestimate risks during periods of high growth, thus loosening credit standards and attracting lower quality of borrowers on average. This in turn will lead to higher credit losses during an economic downturn (Arcalean and others, 2007). In addition, the speed of credit growth may put a strain on banks' risk assessment and management capacities, which may lead to credit misallocation (Hilbers and other, 2005). When investment avenues in a country are limited, banks may concentrate lending to a particular sector, overexposing themselves to potential adverse shocks to that sector and/or generating mismatches between the maturity of their assets and liabilities.

\section{Several prudential indicators point to the general health of the banking sector in}

Bhutan. However, significant differences between the performance and strategies of the two banks in Bhutan should be noted. Despite the ongoing credit expansion, both banks are wellcapitalized and liquid, with healthy profitability and low nonperforming loan ratios. Audited data from December 2005 and December 2006 indicate that return on equity for the financial sector as a whole has increased from $15^{1 / 4}$ percent to $16 \frac{1}{2}$ percent, with both banks registering an improvement in their profitability. The banking sector maintains adequate buffers, well in excess of the minimum requirements. The capital adequacy ratio (CAR) for the two banks declined slightly from its 2005 level, but it stands at a comfortable 17 percent as compared to the minimum requirement of 8 percent. The nonbank financial institutions 
maintained an even higher CAR of 36 percent. Judging from the change in nonperforming loan ratios over the past two years, asset quality seems to have improved in the banking sector. The NPL ratio dropped from7 percent to 5 percent, with the decline driven by an almost flat absolute amount of NPL. Among the nonbanks however, NPL ratios were and continue to be very elevated, comprising almost a quarter of total loans.

\section{The positive indicators notwithstanding, there is substantial sectoral} concentration in the financial institutions' asset portfolios. The bulk of private sector credit was extended for the housing and construction sector boosted by rising property prices. These borrowings are inherently long term, which creates vulnerability for the banks whose liabilities are of much shorter maturity. In addition, despite the low NPL ratios within the housing sector loans at present, a decline in real estate prices would likely lead to a deterioration in asset quality.

\section{Stress testing of the banking sector suggests that the banking system is relatively}

shielded from shocks. Stress tests were used to quantify the impact of various shocks on key measures of banking system soundness, such as the capital adequacy ratio and NPL ratios (Cihak, 2007). The shocks considered were (i) a 25 percent increase in NPLs proportional to existing NPLs; (ii) a 25 percent increase in NPLs proportional to performing loans;

(iii) 25 percent of performing loans in the housing/construction sector becoming NPLs; and (iv) an appreciation of the ngultrum by 10 percent.

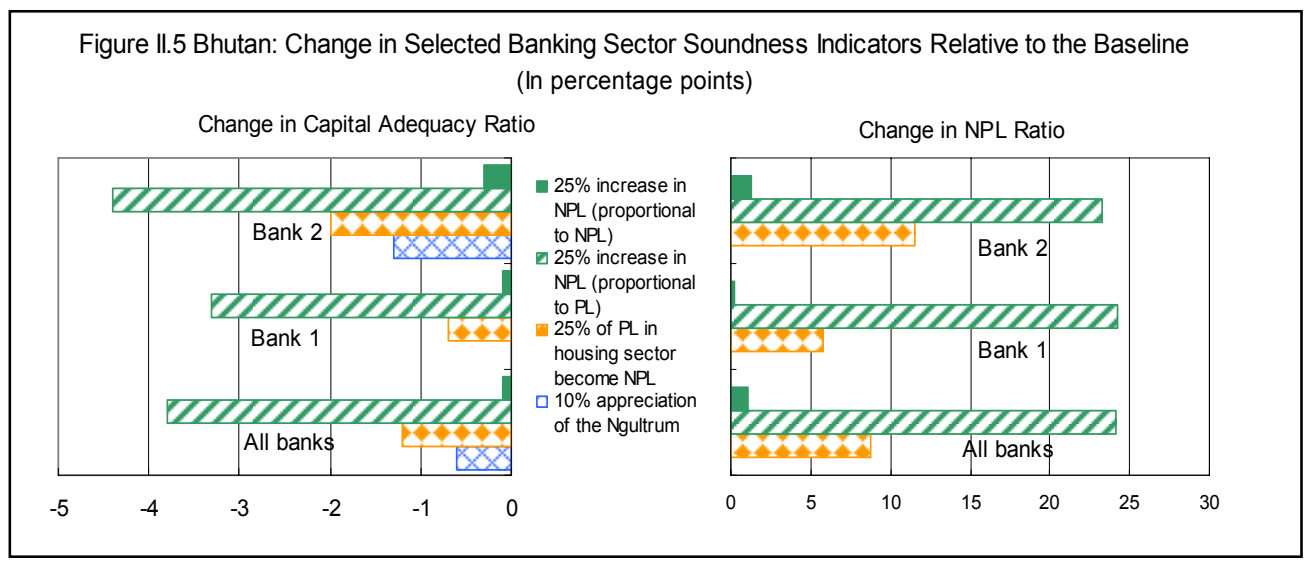

- $\quad$ The banking sector CAR declines by varying amounts but remains above the 8 percent required minimum under all shocks. The range of decline is 0.1-3.8 percentage points for the banking system as a whole. The large decline in the CAR from a 25 percent increase in NPLs proportional to performing loans. 
- An appreciation of the ngultrum slightly lowers the capital adequacy ratio of the banking sector. The entire effect stems from one of the banks which has a sizable net open position.

- $\quad$ The NPL ratio is substantially more sensitive to the shocks analyzed. A decline in the quality of the housing and construction sector loans leads to an increase in NPLs, corroborating the potential negative impact a sharp decline of housing prices may have on the health of the banking sector.

- The low existing levels of interbank lending limit potential contagion within the financial sector.

\section{Conclusion}

\section{Strong economic growth will require and lead to a deepening and further} development of the financial system in Bhutan. However, rapid credit expansion can also expose the economy to macroeconomic and financial risks that require careful monitoring. The findings of this chapter suggest that the strong growth of credit to the private sector may have been accompanied by growing vulnerabilities on the external side. While there are no signs of domestic overheating as of now and inflation has generally been contained, growth in non-hydropower related imports has been strong. In recent months, short-term problems of rupee reserve management have also emerged, partially a by-product of the strong growth in credit. However, there are a number of mitigating factors. Current account deficits have been matched by capital inflows in the form of concessional loans and grants. Moreover, despite the sharp decline in rupee reserves, total foreign exchange reserves have continued to increase and remain at a comfortable level.

\section{The financial sector seems to be relatively shielded from adverse events, though} risks remain. The significant sectoral concentration in the financial institutions' asset portfolio has created an asset/liability maturity mismatch and could lead to a sharp deterioration in banks' asset quality in the case of a negative correction in the housing market.

\section{To reap the full benefits of credit expansion and minimize the vulnerabilities that might arise from it, several steps could be taken:}

- $\quad$ The RMA needs to ensure that the excess liquidity does not translate into excessive credit growth through several measures:

- Issuance of RMA bills could be stepped up and the interest rate could be increased and more closely aligned with monetary policy in India.

- The CRR should be raised, and provisioning against housing/construction loans could be increased to cool down real estate lending. Effective December 2007, the 
provisioning rate on substandard and doubtful loans is to be raised from 20 percent to 30 percent and from 50 percent to 60 percent on housing loans effective. The RMA was also in the process of increasing the CRR from 13 percent to 15 percent.

- $\quad$ Bank supervision and regulation should be strengthened ensuring that banks' risk management practices are up to the challenges of a rapid expansion of credit. Regular stress testing of the resilience of the banking sector should be performed.

- With the ngultrum peg, fiscal policy should be used to contain demand pressures that may worsen non-hydropower related current account deficits or generate inflationary pressures. 


\section{References}

Arcalean, C., O. Calvo-Gonzalez, C. More, A. van Rixtel, A. Winkler, and T. Zumer, 2007, "The Causes and Nature of the Rapid Growth of Bank Credit in the Central, Eastern and South-Eastern European Countries," in Rapid Credit Growth in Central and Eastern Europe. Endless Boom or Early Warning?, ed. by Charles Enoch and Inci Otker-Robe, International Monetary Fund (London, United Kingdom: Palgrave Macmillan).

Cihak, Martin, 2007, “Introduction to Applied Stress Testing,” IMF Working Paper 07/59 (Washington: International Monetary Fund).

Hilbers, P., I.Otker-Robe, C. Pazarbasioglu, and C. Johnsen, 2005, “Assessing and Managing Rapid Credit Growth and the Role of Supervisory and Prudential Policies," IMF Working Paper 05/151 (Washington: International Monetary Fund).

International Monetary Fund, 2004, "Are Credit Booms in Emerging Markets a Concern?" Chapter IV in World Economic Outlook, April 2004: Advancing Structural Reforms, World Economic and Financial Surveys (Washington).

Wangdi, Phuntsho, “Bhutan’s Software Industry?,” Kuensel Online, August 11, 2007. Available via the Internet: http://www.kuenselonline.com/modules.php?name=News\& file=article \&sid=8879.

Levine, Ross, 2005, "Finance and Growth: Theory and Evidence," in Handbook of Economic Growth, ed. by Philippe Aghion and Steven Durlauf (The Netherlands: Elsevier Science). , 1997, "Financial Development and Economic Growth: Views and Agenda," Journal of Economic Literature, Vol. 35(2), pp. 668-726. 
Table 1. Bhutan: Gross Domestic Product by Origin at 2000 Prices, 2001-2005

\begin{tabular}{|c|c|c|c|c|c|}
\hline & 2001 & 2002 & 2003 & 2004 & 2005 \\
\hline & \multicolumn{5}{|c|}{ (In millions of ngultrum) } \\
\hline 1. Agriculture, livestock, and forestry & 5,849 & 6,009 & 6,138 & 6,266 & 6,274 \\
\hline 1.1 Agriculture proper & 2,617 & 2,689 & 2,766 & 2,824 & 2,861 \\
\hline 1.2 Livestock & 1,888 & 1,919 & 1,927 & 1,933 & 1,976 \\
\hline 1.3 Forestry and logging & 1,345 & 1,401 & 1,446 & 1,509 & 1,437 \\
\hline 2. Mining and quarrying & 352 & 389 & 402 & 381 & 433 \\
\hline 3. Manufacturing & 1,656 & 1,733 & 1,770 & 1,868 & 1,951 \\
\hline 4. Electricity \& water & 2,185 & 2,561 & 3,030 & 2,980 & 3,284 \\
\hline 5. Construction & 3,461 & 4,329 & 4,448 & 4,819 & 4,679 \\
\hline 6. Wholesale and retail trade & 1,029 & 1,234 & 1,378 & 1,633 & 1,878 \\
\hline 7. Hotel and restaurant & 112 & 115 & 129 & 157 & 186 \\
\hline 8. Transport, storage, and communication & 1,844 & 2,000 & 2,007 & 2,448 & 2,627 \\
\hline 9. Financing, insurance \& real estate & 1,534 & 1,296 & 1,745 & 1,944 & 2,441 \\
\hline 9.1. Finance \& insurance & 937 & 747 & 1,054 & 1,245 & 1,724 \\
\hline 9.2. Real estate \& dwellings & 597 & 549 & 691 & 699 & 717 \\
\hline 10.Community, social services & 2,847 & 3,051 & 3,288 & 3,308 & 3,743 \\
\hline 11. Private social, personal \& recreational services & 97 & 100 & 110 & 120 & 142 \\
\hline 12. Plus taxes net of subsidies & 533 & 829 & 987 & 1,231 & 1,401 \\
\hline Gross domestic product & 21,498 & 23,646 & 25,432 & 27,155 & 29,039 \\
\hline Change in percent & 7.2 & 10.0 & 7.6 & 6.8 & 6.9 \\
\hline
\end{tabular}

Source: National Accounts Statistics, 2006, National Statistical Bureau. 
Table 2. Bhutan: Gross Domestic Product by Origin at Current Prices, 2001-2005

\begin{tabular}{lrrrrr}
\hline & 2001 & 2002 & 2003 & 2004 & 2005 \\
& & & & & \\
& & & & & \\
& & & & \\
& & & & & \\
& & & & \\
& & & & \\
& 6,037 & 6,884 & 7,292 & 7,864 & 8,256 \\
& 2,682 & 3,000 & 3,192 & 3,481 & 3,685 \\
1. Agriculture, livestock, and forestry & 1,930 & 2,007 & 2,163 & 2,331 & 2,557 \\
1.1 Agriculture proper & 1,425 & 1,877 & 1,938 & 2,052 & 2,014 \\
1.2 Livestock & & & & & \\
1.3 Forestry and logging & 344 & 440 & 581 & 440 & 538 \\
& 1,855 & 1,945 & 2,042 & 2,384 & 2,688 \\
2. Mining and quarrying & 2,279 & 2,658 & 3,352 & 3,085 & 3,661 \\
3. Manufacturing & 3,818 & 4,711 & 5,020 & 5,630 & 6,353 \\
4. Electricity and water & 1,045 & 1,283 & 1,447 & 1,726 & 2,089 \\
5. Construction & 113 & 120 & 135 & 169 & 212 \\
6. Wholesale and retail trade & 2,083 & 2,452 & 2,626 & 3,295 & 3,838 \\
7. Hotel and restaurant & 1,596 & 1,434 & 1,924 & 2,234 & 2,799 \\
8. Transport, storage, and communication & 950 & 717 & 1,002 & 1,233 & 1,690 \\
9. Financing, insurance \& real estate & 645 & 716 & 922 & 1,001 & 1,109 \\
$\quad$ 9.1. Finance \& insurance & 3,037 & 3,342 & 3,664 & 3,823 & 4,472 \\
9.2. Real estate \& dwellings & 99 & 108 & 119 & 136 & 164 \\
10. Community, social services & 551 & 878 & 1,068 & 1,393 & 1,668 \\
11. Private social, personal \& recreational services & & & & & \\
12. Plus: taxes net of subsidies & 22,858 & 26,254 & 29,269 & 32,178 & 36,737 \\
& & & & & \\
Gross domestic product & & & & \\
& & & &
\end{tabular}

Source: National Accounts Statistics, 2006, National Statistical Bureau. 
Table 3. Bhutan: Crop Production Estimates, 2001-2005

\begin{tabular}{|c|c|c|c|c|c|}
\hline & 2001 & 2002 & 2003 & 2004 & 2005 \\
\hline & \multicolumn{5}{|c|}{ (In thousands of acres) } \\
\hline \multicolumn{6}{|l|}{ Area } \\
\hline Paddy & 48.3 & 48.5 & 48.7 & 46.6 & 62.5 \\
\hline Wheat/barley & 15.0 & 15.0 & 69.4 & 10.4 & 30.3 \\
\hline Maize & 78.8 & 79.0 & 9.6 & 53.9 & 75.9 \\
\hline Buckwheat/millet & 23.4 & 23.6 & 19.7 & 13.7 & 33.0 \\
\hline Potatoes & 8.1 & 8.5 & 10.2 & 8.5 & 14.5 \\
\hline Chilies & 2.9 & 3.0 & 3.4 & 3.1 & 5.6 \\
\hline Mustard & 9.4 & 9.5 & 5.1 & 4.5 & 14.0 \\
\hline \multicolumn{6}{|c|}{ (In metric tons per acres) } \\
\hline \multicolumn{6}{|l|}{ Yield } \\
\hline Paddy & 1.5 & 1.6 & 0.9 & 1.2 & 1.1 \\
\hline Wheat/barley & 0.4 & 0.5 & 0.6 & 1.1 & 1.1 \\
\hline Maize & 1.1 & 1.2 & 0.7 & 1.7 & 1.2 \\
\hline Buckwheat/millet & 0.3 & 0.3 & 0.3 & 1.5 & 1.6 \\
\hline Potatoes & 4.7 & 5.0 & 3.9 & 5.6 & 3.7 \\
\hline Chilies & 1.4 & 1.6 & $\ldots$ & 1.5 & 1.9 \\
\hline Mustard & 0.3 & 0.4 & 0.3 & 0.4 & 0.3 \\
\hline \multicolumn{6}{|c|}{ (In thousands of metric tons) } \\
\hline \multicolumn{6}{|l|}{ Production } \\
\hline Paddy & 70.3 & 73.4 & 45.9 & 54.3 & 67.6 \\
\hline Wheat/barley & 6.1 & 6.5 & 57.5 & 5.6 & 15.8 \\
\hline Maize & 79.2 & 79.5 & 49.7 & 90.6 & 94.0 \\
\hline Buckwheat/millet & 6.5 & 6.6 & 5.1 & 4.9 & 13.8 \\
\hline Potatoes & 36.5 & 38 & 40.6 & 47.4 & 53.6 \\
\hline Chilies & 3.2 & 3.5 & 0.0 & 4.5 & 10.4 \\
\hline Mustard & 1.9 & 2.1 & 3.6 & 1.8 & 4.4 \\
\hline
\end{tabular}

Source: Data provided by the Bhutanese authorities. 
Table 4. Bhutan: Livestock and Poultry Production, 2000-2004

\begin{tabular}{|c|c|c|c|c|c|}
\hline & 2000 & 2001 & 2002 & 2003 & 2004 \\
\hline Cattle & 321 & 330 & 326 & 314 & 269 \\
\hline Yaks & 33 & 34 & 34 & 19 & 19 \\
\hline Sheep/goats & 54 & 56 & 56 & 5 & 5 \\
\hline Pigs & 41 & 42 & 43 & 20 & 20 \\
\hline Poultry & 231 & 242 & 249 & 45 & 45 \\
\hline
\end{tabular}

Source: Ministry of Agriculture. 
Table 5. Bhutan: Logging Volume, 2001-2005

(In cubic meters)

\begin{tabular}{lrrrrr}
\hline & 2001 & 2002 & 2003 & 2004 & 2005 \\
\hline $\begin{array}{l}\text { Commercial logging } \\
\text { Logging for housing construction } \\
\text { and public works plus other uses }\end{array}$ & 44,209 & 48,878 & 49,826 & 54,347 & 53,924 \\
Total & 6,765 & 11,134 & 7,393 & 9,766 & 7,981 \\
\hline
\end{tabular}

Source: Forestry Development Corporation, Ministry of Agriculture. 
Table 6. Bhutan: Imports of Essential Food Items by the Food Corporation of Bhutan, 2001-2005

(In metric tons)

\begin{tabular}{lrrrrr}
\hline & 2001 & 2002 & 2003 & 2004 & 2005 \\
\hline Rice & 6,599 & 7,434 & 18,263 & 7,188 & 6,227 \\
Wheat & 1,371 & 2,310 & 2,626 & 2,500 & 36 \\
Wheat/wheat products & 7,076 & 17,680 & 14,807 & 14,655 & 319 \\
Sugar & 3,155 & 1,925 & 1,181 & 1,966 & 3,924 \\
Edible oils ('000 litters) & 162 & 380 & 636 & 198 & 569 \\
\hline
\end{tabular}

Source: Food Corporation of Bhutan. 
Table 7. Bhutan: Gross Sales and Output of Selected Industries, 2001-2005

(In millions of ngultrum)

\begin{tabular}{lccccc}
\hline & 2001 & 2002 & 2003 & 2004 & 2005 \\
& & & & & \\
\hline Penden Cement Authority & 764 & 814 & 896 & 852 & 807 \\
Bhutan Ferro Alloys Limited & 579 & 643 & 658 & 748 & 651 \\
Bhutan Fruit Products & 112 & 134 & 122 & 174 & 69 \\
Bhutan Carbide and Chemicals & 676 & 708 & 703 & 732 & 760 \\
Bhutan Board Products & 294 & 289 & 492 & 546 & 158 \\
\hline
\end{tabular}

Source: Department of Trade and Industry. 
Table 8. Bhutan: Electricity Generation, Tariff Rates, and Trade with India, 2001/02-2005/06

\begin{tabular}{|c|c|c|c|c|c|}
\hline & $2001 / 02$ & $2002 / 03$ & $2003 / 04$ & $2004 / 05$ & $2005 / 06$ \\
\hline & \multicolumn{5}{|c|}{ (In millions of kilowatt hours) } \\
\hline Domestic generation & $2,059.4$ & $2,200.5$ & $2,528.7$ & $2,355.0$ & $2,647.4$ \\
\hline Hydroelectric power & $2,059.0$ & $2,199.6$ & $2,526.6$ & $2,353.2$ & $2,645.8$ \\
\hline Diesel & 0.5 & 0.9 & 2.1 & 1.8 & 1.5 \\
\hline Purchases from India & 6.9 & 2.6 & 2.3 & 2.3 & 2.5 \\
\hline \multirow[t]{2}{*}{ Total supply of electricity } & $2,066.3$ & $2,203.0$ & $2,530.9$ & $2,357.3$ & $2,649.8$ \\
\hline & \multicolumn{5}{|c|}{ (In millions of ngultrum) } \\
\hline \multirow[t]{2}{*}{ Exports to India } & 2,218 & 2,364 & 2,805 & 2,585 & 3,510 \\
\hline & \multicolumn{5}{|c|}{ (In ngultrum per unit) } \\
\hline Export tariff to India $1 /$ & 1.50 & 1.50 & 1.50 & $1.75-2.0$ & $1.75-2.0$ \\
\hline \multicolumn{6}{|l|}{ Domestic tariff rates 2/ } \\
\hline Below 80 Kwh per month & $\ldots$ & 0.6 & 0.6 & 0.6 & 0.6 \\
\hline Above $200 \mathrm{Kwh}$ per month & 0.8 & 0.8 & 1.0 & 1.2 & 1.3 \\
\hline
\end{tabular}

Source: Department of Energy.

1/ Rates shown are for Chukha exports and were in effect from April 1, 1995 to March 31, 1997, from April 1, 1997 to June 30, 1999, and from July 1, 1999 to end-2004.

2/ Tariff rates for low voltage electricity. A lifeline tariff rate of Nu 0.6 for the first $80 \mathrm{Kwh}$ of consumption was introduced in 2002/03. 
Table 9. Bhutan: Tourism Statistics, 2002-2006 1/

\begin{tabular}{|c|c|c|c|c|c|}
\hline & 2002 & 2003 & 2004 & 2005 & 2006 \\
\hline Hotel rooms available (number) $2 /$ & 1,239 & 1,270 & 1,202 & 1,548 & 1,532 \\
\hline Average length of stay (nights) & 7.0 & 7.0 & 8.0 & 8.5 & 8.0 \\
\hline Total tourism receipts (in millions of U.S. dollars) & 8.0 & 8.3 & 12.5 & 18.5 & 23.9 \\
\hline Tourist arrivals (number) & 5,599 & 6,261 & 9,249 & 13,625 & 17,909 \\
\hline \multicolumn{6}{|l|}{ Tourist arrivals by country } \\
\hline Total Europe & 2,015 & 2,671 & 3,478 & 4,973 & 6,848 \\
\hline Germany & 346 & 496 & 671 & 1,042 & 1,074 \\
\hline France & 192 & 288 & 434 & 532 & 708 \\
\hline Italy & 177 & 331 & 462 & 529 & 648 \\
\hline Other Europe & 1,300 & 1,556 & 1,911 & 2,870 & 4,418 \\
\hline United States & 1,913 & 1,803 & 3,243 & 4,681 & 5,018 \\
\hline Japan & 892 & 952 & 1,087 & 1,554 & 1815 \\
\hline Australia & 214 & 165 & 315 & 458 & 774 \\
\hline Other & 565 & 670 & 1,126 & 1,959 & 3,454 \\
\hline \multicolumn{6}{|l|}{ Tourist arrivals by purpose } \\
\hline Touring & 5,242 & 5,823 & 8,742 & 13,013 & 16,578 \\
\hline Trekking & 357 & 438 & 507 & 612 & 1,331 \\
\hline
\end{tabular}

Source: Department of Tourism, Ministry of Trade and Industry.

$1 /$ Data relate to tourists paying in convertible currencies.

2/ Includes hotels approved by the Department of Tourism. 


\section{Table 10. Bhutan: Consumer Price Index, 2002-2006 1/}

$(1979=100$, unless otherwise indicated $)$

\begin{tabular}{|c|c|c|c|c|c|c|}
\hline \multirow[b]{2}{*}{ (Weight) } & \multirow{2}{*}{$\begin{array}{c}\text { Food } \\
\text { Items } \\
(72.3)\end{array}$} & \multirow{2}{*}{$\begin{array}{r}\text { Nonfood } \\
\text { Items } \\
(27.7)\end{array}$} & \multirow{2}{*}{$\begin{array}{r}\text { All Items } \\
(100.0)\end{array}$} & \multicolumn{3}{|c|}{ Annual Percentage Change in: } \\
\hline & & & & Food & Nonfood & Total \\
\hline \multicolumn{7}{|l|}{2002} \\
\hline $\mathrm{H} 1$ & 525.9 & 924.0 & 636.1 & 2.2 & 3.7 & 2.7 \\
\hline $\mathrm{H} 2$ & 535.6 & 938.7 & 647.2 & 2.0 & 2.7 & 2.3 \\
\hline \multicolumn{7}{|l|}{2003} \\
\hline $\mathrm{H} 1$ & 535.0 & 942.4 & 647.8 & 1.7 & 2.0 & 1.8 \\
\hline Q3 & 100.0 & 100.0 & 100.0 & $\ldots$ & $\ldots$ & $\ldots$ \\
\hline Q4 & 101.4 & 102.3 & 102.0 & $\ldots$ & $\ldots$ & $\ldots$ \\
\hline \multicolumn{7}{|l|}{2004} \\
\hline Q1 & 101.9 & 104.7 & 103.8 & $\ldots$ & $\ldots$ & $\ldots$ \\
\hline Q2 & 101.1 & 104.7 & 103.6 & $\ldots$ & $\ldots$ & $\ldots$ \\
\hline Q3 & 102.9 & 105.3 & 104.6 & 2.8 & 5.3 & 4.6 \\
\hline Q4 & 104.2 & 106.9 & 106.0 & 2.7 & 4.5 & 3.9 \\
\hline \multicolumn{7}{|l|}{2005} \\
\hline Q1 & 108.0 & 110.0 & 109.4 & 6.1 & 5.1 & 5.4 \\
\hline Q2 & 107.4 & 110.1 & 109.2 & 6.2 & 5.1 & 5.5 \\
\hline Q3 & 108.7 & 111.0 & 110.3 & 5.7 & 5.4 & 5.5 \\
\hline Q4 & 109.4 & 112.1 & 111.2 & 5.0 & 4.9 & 4.9 \\
\hline \multicolumn{7}{|l|}{2006} \\
\hline Q1 & 110.3 & 114.0 & 112.8 & 2.1 & 3.6 & 3.1 \\
\hline Q2 & 114.6 & 116.6 & 116.0 & 6.8 & 5.9 & 6.2 \\
\hline Q3 & 115.0 & 116.8 & 116.2 & 5.8 & 5.2 & 5.4 \\
\hline Q4 & 115.1 & 118.1 & 117.1 & 5.2 & 5.3 & 5.3 \\
\hline
\end{tabular}

Sources: National Statistical Bureau; and CEIC Data Company Ltd.

$1 /$ The consumer price index was re-based in the third quarter of 2003 , and the frequency was changed to quarterly. Weights for the quarterly CPI also changed as follows: food (31.7); nonfood (68.3); total (100.0). 
Table 11. Bhutan: Government Budget Summary, 2001/02-2006/07

\begin{tabular}{|c|c|c|c|c|c|c|}
\hline & $2001 / 02$ & $2002 / 03$ & $2003 / 04$ & $2004 / 05$ & $2005 / 06$ & $\frac{2006 / 07}{\text { Budget }}$ \\
\hline & \multicolumn{6}{|c|}{ (In millions of ngultrum) } \\
\hline Revenue and grants & 8,849 & 7,054 & 10,421 & 10,439 & 13,328 & 16,357 \\
\hline Revenue & 5,100 & 4,785 & 5,055 & 6,066 & 6,903 & 10,122 \\
\hline Tax revenue & 2,415 & 2,728 & 2,467 & 3,069 & 3,717 & 5,139 \\
\hline Nontax revenue & 2,685 & 2,057 & 2,589 & 2,997 & 3,186 & 4,983 \\
\hline Grants & 3,749 & 2,269 & 5,366 & 4,373 & 6,425 & 6,235 \\
\hline From India & 2,532 & 929 & 3,533 & 2,625 & 3,417 & 4,175 \\
\hline Other & 1,217 & 1,340 & 1,833 & 1,748 & 3,007 & 2,060 \\
\hline Expenditure and net lending & 10,053 & 9,945 & 9,865 & 12,893 & 13,771 & 17,902 \\
\hline Current expenditure & 4,468 & 4,581 & 5,149 & 6,171 & 6,672 & 7,962 \\
\hline Capital expenditure & 5,313 & 5,413 & 5,265 & 6,810 & 6,809 & 9,814 \\
\hline Net lending & 272 & -48 & -549 & -88 & 289 & 126 \\
\hline Current balance (excluding grants) & 632 & 204 & -94 & -105 & 231 & 2,160 \\
\hline Overall balance (including grants) & $-1,204$ & $-2,891$ & 556 & $-2,454$ & -443 & $-1,545$ \\
\hline Financing & 1,204 & 2,891 & -556 & 2,454 & 443 & 1,545 \\
\hline Foreign financing & 1,397 & 1,537 & 932 & 739 & 715 & 811 \\
\hline Disbursement & 1,607 & 1,759 & 1,149 & 1,137 & 1,114 & 1,287 \\
\hline Amortization & 210 & 221 & 217 & 398 & 398 & 477 \\
\hline \multirow[t]{2}{*}{ Domestic financing } & -193 & 1,353 & $-1,488$ & 1,714 & -272 & 734 \\
\hline & \multicolumn{6}{|c|}{ (In percent of GDP) } \\
\hline Revenue and grants & 36.0 & 25.4 & 33.9 & 30.3 & 33.9 & 34.1 \\
\hline Domestic revenue & 20.8 & 17.2 & 16.5 & 17.6 & 17.6 & 21.1 \\
\hline Of which: tax revenue & 9.8 & 9.8 & 8.0 & 8.9 & 9.5 & 10.7 \\
\hline Foreign grants & 15.3 & 8.2 & 17.5 & 12.7 & 16.3 & 13.0 \\
\hline Expenditure and net lending & 40.9 & 35.8 & 32.1 & 37.4 & 35.0 & 37.3 \\
\hline Current expenditure & 18.2 & 16.5 & 16.8 & 17.9 & 17.0 & 16.6 \\
\hline Capital expenditure and net lending & 22.7 & 19.3 & 15.3 & 19.5 & 18.1 & 20.7 \\
\hline Current balance (excluding grants) & 2.6 & 0.7 & -0.3 & -0.3 & 0.6 & 4.5 \\
\hline Overall balance (including grants) & -4.9 & -10.4 & 1.8 & -7.1 & -1.1 & -3.2 \\
\hline \multicolumn{7}{|l|}{ Memorandum item: } \\
\hline Nominal GDP (in millions of ngultrum) & 24,556 & 27,762 & 30,724 & 34,458 & 39,317 & 47,996 \\
\hline
\end{tabular}

Sources: Data provided by the Bhutanese authorities; and staff estimates. 
Table 12. Bhutan: Government Revenue, 2000/01-2005/06

(In millions of ngultrum)

\begin{tabular}{|c|c|c|c|c|c|c|}
\hline & $2000 / 01$ & $2001 / 02$ & $2002 / 03$ & $2003 / 04$ & $2004 / 05$ & $2005 / 06$ \\
\hline Tax revenue & 1,917 & 2,415 & 2,728 & 2,467 & 3,069 & 3,717 \\
\hline Tax on income and profits & 1,258 & 1,379 & 1,373 & 1,533 & 1,530 & 1,833 \\
\hline Of which: Chukha revenue & 618 & 593 & 539 & 585 & 562 & 737 \\
\hline Taxes on domestic goods & 473 & 805 & 1,093 & 625 & 1,134 & 1,542 \\
\hline Taxes on international trade & 91 & 107 & 116 & 154 & 232 & 158 \\
\hline Other & 94 & 124 & 146 & 155 & 174 & 184 \\
\hline Nontax revenue & 2,755 & 2,685 & 2,057 & 2,589 & 2,997 & 3,186 \\
\hline Net profit transfers & 714 & 315 & 317 & 198 & 384 & 503 \\
\hline Royalties & 275 & 214 & 215 & 243 & 332 & 407 \\
\hline Dividends & 1,296 & 1,427 & 1,288 & 1,753 & 1,551 & 1,542 \\
\hline Of which: Chukha revenue & 1,201 & 1,248 & 1,083 & 1,621 & 1,362 & 1,356 \\
\hline Administrative fees and charges & 81 & 137 & 148 & 129 & 169 & 197 \\
\hline Sale of government property & 47 & 28 & 25 & 74 & 233 & 168 \\
\hline Revenue from government departments & 311 & 500 & 34 & 41 & 79 & 102 \\
\hline Other & 31 & 64 & 30 & 151 & 250 & 266 \\
\hline Total revenue & 4,672 & 5,100 & 4,785 & 5,055 & 6,066 & 6,903 \\
\hline
\end{tabular}

Source: Data provided by the Bhutanese authorities. 
Table 13. Bhutan: Economic Classification of Government Current Expenditure, 2000/01-2005/06

(In millions of ngultrum)

\begin{tabular}{|c|c|c|c|c|c|c|}
\hline & $2000 / 01$ & $2001 / 02$ & $2002 / 03$ & $2003 / 04$ & $2004 / 05$ & $2005 / 06$ \\
\hline Wages and salaries & 1,582 & 1,746 & 1,845 & 1,980 & 2,398 & 2,817 \\
\hline Goods and services & 2,028 & 2,114 & 2,093 & 2,416 & 2,872 & 3,020 \\
\hline Subsidies and transfers & 748 & 445 & 474 & 533 & 496 & 453 \\
\hline Druk Air Corporation & 29 & 25 & 21 & 65 & 134 & 142 \\
\hline Bhutan Broadcasting Corporation & 16 & 18 & 23 & 29 & 34 & 36 \\
\hline $\begin{array}{l}\text { Individuals and other nonprofit } \\
\text { organizations }\end{array}$ & 498 & 229 & 262 & 293 & 175 & 140 \\
\hline Gratuity and retirement benefits & 42 & 48 & 48 & 32 & 38 & 35 \\
\hline Contribution to Provident Fund & 141 & 151 & 102 & 107 & 115 & 123 \\
\hline Other & 22 & -26 & 18 & 7 & 0 & -23 \\
\hline Interest payments & 78 & 116 & 169 & 220 & 405 & 382 \\
\hline Total current expenditures & 4,436 & 4,468 & 4,581 & 5,149 & 6,171 & 6,672 \\
\hline
\end{tabular}

Source: Data provided by the Bhutanese authorities. 
Table 14. Bhutan: Functional Classification of Government Current Expenditure, 2000/01-2005/06

\begin{tabular}{|c|c|c|c|c|c|c|}
\hline & $2000 / 01$ & $2001 / 02$ & $2002 / 03$ & $2003 / 04$ & $2004 / 05$ & $2005 / 06$ \\
\hline & \multicolumn{6}{|c|}{ (In millions of ngultrum) } \\
\hline General public services & 2,026 & 1,748 & 2,090 & 2,692 & 3,133 & 3,322 \\
\hline Economic services & 1,036 & 1,199 & 838 & 812 & 919 & 1,090 \\
\hline Agriculture and irrigation & 249 & 282 & 201 & 159 & 193 & 230 \\
\hline Animal husbandry & 94 & 99 & 113 & 110 & 129 & 155 \\
\hline Forestry & 153 & 169 & 184 & 205 & 238 & 276 \\
\hline Industries, mining, trade, and commerce & 58 & 56 & 57 & 51 & 66 & 79 \\
\hline Public works, roads, and housing & 179 & 234 & 225 & 60 & 237 & 275 \\
\hline Transport and communication & 30 & 34 & 36 & 201 & 27 & 38 \\
\hline Power & 272 & 326 & 23 & 27 & 29 & 37 \\
\hline Social services & 1,375 & 1,521 & 1,653 & 1,642 & 2,119 & 2,260 \\
\hline Education & 833 & 892 & 1,070 & 1,010 & 1,375 & 1,395 \\
\hline Health & 525 & 610 & 562 & 601 & 642 & 734 \\
\hline \multicolumn{7}{|l|}{ Urban development and municipal } \\
\hline \multirow[t]{2}{*}{ corporations } & 16 & 19 & 21 & 31 & 102 & 130 \\
\hline & \multicolumn{6}{|c|}{ (In percent of total current expenditure) } \\
\hline General public services & 45.7 & 39.1 & 45.6 & 52.3 & 50.8 & 49.8 \\
\hline Economic services & 23.3 & 26.8 & 18.3 & 15.8 & 14.9 & 16.3 \\
\hline Social services & 31.0 & 34.0 & 36.1 & 31.9 & 34.3 & 33.9 \\
\hline
\end{tabular}

Source: Data provided by the Bhutanese authorities. 
Table 15. Bhutan: Functional Classification of Government Capital Expenditure, 2000/01-2005/06

\begin{tabular}{|c|c|c|c|c|c|c|}
\hline & $2000 / 01$ & $2001 / 02$ & $2002 / 03$ & $2003 / 04$ & $2004 / 05$ & $2005 / 06$ \\
\hline & \multicolumn{6}{|c|}{ (In millions of ngultrum) } \\
\hline General public services & 1,078 & 806 & 1,776 & 1,548 & 3,338 & 2,320 \\
\hline Economic services & 4,505 & 3,448 & 2,822 & 2,546 & 2,425 & 3,300 \\
\hline Agriculture and irrigation & 211 & 304 & 155 & 386 & 166 & 342 \\
\hline Animal husbandry & 16 & 109 & 382 & 42 & 36 & 104 \\
\hline Forestry & 122 & 203 & 81 & 87 & 108 & 123 \\
\hline Industries, mining, trade, and commerce & 51 & 163 & 154 & 54 & 63 & 90 \\
\hline Public works, roads, and housing & 1,003 & 1,495 & 1,014 & 409 & 1,835 & 2,033 \\
\hline Transport and communication & 25 & 49 & 43 & 806 & 43 & 169 \\
\hline Power & 3,078 & 1,126 & 992 & 763 & 174 & 440 \\
\hline Social services & 698 & 1,059 & 712 & 559 & 852 & 1,065 \\
\hline Education & 382 & 630 & 406 & 294 & 463 & 693 \\
\hline Health & 279 & 388 & 287 & 231 & 310 & 312 \\
\hline \multicolumn{7}{|l|}{ Urban development and municipal } \\
\hline \multirow[t]{2}{*}{ corporations } & 37 & 41 & 19 & 34 & 79 & 60 \\
\hline & \multicolumn{6}{|c|}{ (In percent of total capital expenditure 1/) } \\
\hline General public services & 17.2 & 15.2 & 32.8 & 29.4 & 49.0 & 34.1 \\
\hline Economic services & 71.7 & 64.9 & 52.1 & 48.4 & 35.6 & 48.5 \\
\hline Social services & 11.1 & 19.9 & 13.2 & 10.6 & 12.5 & 15.6 \\
\hline
\end{tabular}

Source: Data provided by the Bhutanese authorities. 
Table 16. Bhutan: Functional Classification of Total Government Expenditure, 2000/01-2005/06

\begin{tabular}{|c|c|c|c|c|c|c|}
\hline & $2000 / 01$ & $2001 / 02$ & $2002 / 03$ & $2003 / 04$ & $2004 / 05$ & $2005 / 06$ \\
\hline & \multicolumn{6}{|c|}{ (In millions of ngultrum) } \\
\hline General public services & 3,104 & 2,554 & 3,866 & 4,240 & 6,471 & 5,642 \\
\hline Economic services & 5,541 & 4,647 & 3,660 & 3,358 & 3,344 & 4,390 \\
\hline Agriculture and irrigation & 460 & 586 & 356 & 545 & 359 & 571 \\
\hline Animal husbandry & 110 & 208 & 495 & 152 & 165 & 259 \\
\hline Forestry & 275 & 372 & 265 & 292 & 346 & 399 \\
\hline Industries, mining, trade, and commerce & 109 & 219 & 211 & 105 & 128 & 170 \\
\hline Public works, roads, and housing & 1,182 & 1,729 & 1,239 & 469 & 2,072 & 2,308 \\
\hline Transport and communication & 55 & 83 & 79 & 1,007 & 70 & 206 \\
\hline Power & 3,350 & 1,452 & 1,015 & 790 & 204 & 478 \\
\hline Social services & 2,073 & 2,580 & 2,365 & 2,201 & 2,971 & 3,325 \\
\hline Education & 1,215 & 1,522 & 1,476 & 1,303 & 1,838 & 2,088 \\
\hline Health & 804 & 998 & 849 & 832 & 952 & 1,046 \\
\hline \multicolumn{7}{|l|}{ Urban development and municipal } \\
\hline corporations & 53 & 60 & 40 & 66 & 181 & 191 \\
\hline & \multicolumn{6}{|c|}{ (In percent of total expenditure) } \\
\hline General public services & 27.8 & 25.4 & 38.9 & 43.0 & 50.2 & 41.0 \\
\hline Economic services & 49.6 & 46.2 & 36.8 & 34.0 & 25.9 & 31.9 \\
\hline Social services & 18.5 & 25.7 & 23.8 & 22.3 & 23.0 & 24.1 \\
\hline
\end{tabular}

Sources: Data provided by the Bhutanese authorities; and staff calculation. 
Table 17. Bhutan: Monetary Survey, 2001-2007 1/

\begin{tabular}{|c|c|c|c|c|c|c|c|c|}
\hline & 2001 & 2002 & 2003 & 2004 & 2005 & \multicolumn{2}{|c|}{2006} & 2007 \\
\hline & Jun. & Jun. & & Jun. & Jun. & Jun. & Dec. & Feb. \\
\hline & \multicolumn{8}{|c|}{ (In millions of ngultrum) } \\
\hline Net foreign assets & 12,789 & 14,355 & 17,520 & 16,457 & 16,397 & 22,505 & 24,425 & 24,170 \\
\hline Rupee & 2,368 & 2,314 & 3,352 & 3,314 & 3,595 & 3,156 & 3,786 & 2,998 \\
\hline Other & 10,421 & 12,041 & 14,168 & 13,142 & 12,802 & 19,349 & 20,639 & 21,172 \\
\hline Net domestic assets & $-3,474$ & $-3,384$ & $-3,265$ & $-1,625$ & 18 & $-2,019$ & $-3,442$ & $-2,629$ \\
\hline Net claims on government 2/ & -456 & -812 & -465 & $-1,818$ & -691 & $-3,371$ & $-5,184$ & $-4,875$ \\
\hline Claims on nongovernment & 2,474 & 3,025 & 4,173 & 5,987 & 7,245 & 9,300 & 10,608 & 10,915 \\
\hline Public enterprises & 333 & 292 & 415 & 1,203 & 1,276 & 1,278 & 1,269 & 1,234 \\
\hline Joint enterprises & 121 & 122 & 232 & 211 & 140 & 120 & 143 & 403 \\
\hline Nonbank financial institutions & $\ldots$ & $\ldots$ & 391 & 314 & 323 & 559 & 538 & 534 \\
\hline Private sector & 2,020 & 2,611 & 3,135 & 4,260 & 5,506 & 7,342 & 8,658 & 8,744 \\
\hline Other items (net) & $-5,492$ & $-5,597$ & $-6,972$ & $-5,794$ & $-6,535$ & $-7,949$ & $-8,866$ & $-8,669$ \\
\hline Broad money & 9,315 & 10,971 & 14,255 & 14,832 & 16,416 & 20,486 & 20,984 & 21,541 \\
\hline Narrow money & 4,373 & 4,914 & 6,794 & 7,737 & 8,445 & 9,073 & 10,338 & 9,908 \\
\hline Currency & 1,483 & 1,600 & 1,699 & 2,015 & 2,303 & 2,615 & 2,763 & 2,770 \\
\hline Demand deposits & 2,890 & 3,314 & 5,095 & 5,722 & 6,141 & 6,458 & 7,576 & 7,138 \\
\hline Quasi-money & 4,942 & 6,058 & 7,461 & 7,095 & 7,971 & 11,413 & 10,646 & 11,633 \\
\hline & \multicolumn{8}{|c|}{ (Changes in percent of initial stock of broad money) } \\
\hline Broad money & 5.5 & 17.8 & 29.9 & 4.0 & 10.7 & 24.8 & 2.4 & 5.2 \\
\hline Net foreign assets & -5.2 & 16.8 & 28.8 & -7.5 & -0.4 & 37.2 & 9.4 & 8.1 \\
\hline Net domestic assets & 10.7 & 1.0 & 1.1 & 11.5 & 11.1 & -12.4 & -6.9 & -3.0 \\
\hline Net claims on government & 7.4 & -3.8 & 3.2 & -9.5 & 7.6 & -16.3 & -8.9 & -7.3 \\
\hline Claims on private sector & 7.4 & 6.3 & 4.8 & 7.9 & 8.4 & 11.2 & 6.4 & 6.8 \\
\hline Other items (net) & -3.7 & -1.1 & -12.5 & 8.3 & -5.0 & -8.6 & -4.5 & -3.5 \\
\hline \multicolumn{9}{|l|}{ Memorandum items: } \\
\hline Money multiplier 3/ & 2.0 & 1.9 & 1.8 & 1.6 & 1.8 & 1.5 & 1.7 & 1.6 \\
\hline Broad money/GDP & 0.43 & 0.45 & 0.51 & 0.48 & 0.48 & 0.52 & 0.44 & 0.45 \\
\hline Nominal GDP (fiscal year) & 21,459 & 24,556 & 27,762 & 30,724 & 34,458 & 39,317 & 47,996 & 47,996 \\
\hline
\end{tabular}

Source: Data provided by the Bhutanese authorities.

1/ A major reclassification in 2003 renders data before and after January 2003 incomparable.

2/ Includes deposits of some public enterprises and off-budgetary entities. Data differ from the bank financing data reported in the fiscal accounts.

3/ Ratio of broad money to reserve money. 
Table 18. Bhutan: Assets and Liabilities of the Royal Monetary Authority of Bhutan, 2001-2007

(In millions of ngultrum)

\begin{tabular}{|c|c|c|c|c|c|c|c|c|}
\hline & \multirow{2}{*}{$\frac{2001}{\text { Jun. }}$} & \multirow{2}{*}{$\frac{2002}{\text { Jun. }}$} & \multirow{2}{*}{$\frac{2003}{\text { Jun. }}$} & \multirow{2}{*}{$\frac{2004}{\text { Jun. }}$} & \multirow{2}{*}{$\frac{2005}{\text { Jun. }}$} & \multicolumn{2}{|c|}{2006} & \multirow{2}{*}{$\frac{2007}{\text { Feb. }}$} \\
\hline & & & & & & Jun. & Dec. & \\
\hline \multicolumn{9}{|l|}{ Assets } \\
\hline Foreign assets & 8,837 & 10,562 & 12,292 & 13,156 & 13,467 & 18,656 & 18,359 & 22,360 \\
\hline Rupee & 89 & 636 & 864 & 1,822 & 2,070 & 1,507 & 201 & 1,564 \\
\hline Other & 8,748 & 9,926 & 11,428 & 11,334 & 11,398 & 17,148 & 18,159 & 20,796 \\
\hline Gold & 211 & 255 & 43 & 44 & 40 & 47 & 38 & 40 \\
\hline Claims on government & 280 & 127 & 56 & 37 & 100 & 0 & 0 & 0 \\
\hline Claims on joint enterprises $1 /$ & 0 & 0 & 0 & 0 & 0 & 0 & 0 & 0 \\
\hline Claims on commercial banks & 23 & 67 & 147 & 249 & 710 & 591 & 103 & 33 \\
\hline Claims on private sector $2 /$ & 2 & 1 & 1 & 1 & 1 & 3 & 10 & 11 \\
\hline \multicolumn{9}{|l|}{ Liabilities } \\
\hline Foreign liabilities 3/ & 0 & 0 & 0 & 0 & 0 & 0 & 0 & 0 \\
\hline Reserve money & 4,606 & 5,917 & 8,008 & 9,370 & 9,340 & 13,475 & 12,285 & 13,262 \\
\hline Currency outside banks & 1,483 & 1,600 & 1,699 & 2,015 & 2,303 & 2,615 & 2,763 & 2,770 \\
\hline Currency in banks & 77 & 94 & 66 & 93 & 107 & 157 & 146 & 232 \\
\hline Bank deposits & 3,045 & 4,223 & 6,243 & 7,262 & 6,930 & 10,703 & 9,377 & 10,259 \\
\hline RMA bills & 410 & 910 & 700 & 200 & 200 & 200 & 100 & 100 \\
\hline Reserve repurchase & 500 & 0 & 0 & 0 & 0 & 0 & 0 & 0 \\
\hline Government deposits & 61 & 182 & 282 & 415 & 779 & 648 & 1,496 & 1,901 \\
\hline Capital account & 450 & 254 & 93 & 145 & 879 & 1,004 & 1,040 & 1,128 \\
\hline Other items (net) & 3,327 & 3,750 & 3,456 & 3,356 & 3,120 & 3,969 & 3,590 & 6,053 \\
\hline \multicolumn{9}{|l|}{ Memorandum item: } \\
\hline Reserve money (12-month percent change) & -5.1 & 28.5 & 35.3 & 17.0 & -0.3 & 44.3 & -3.5 & $\ldots$ \\
\hline
\end{tabular}

Source: Data provided by the Bhutanese authorities.

$1 /$ Includes other financial institutions.

2/ Includes advances to RMA staff.

3/ Rupee overdraft facilities. 
Table 19. Bhutan: Assets and Liabilities of the Bank of Bhutan, 2001-2007

(In millions of ngultrum)

\begin{tabular}{|c|c|c|c|c|c|c|c|c|}
\hline & \multirow{2}{*}{$\frac{2001}{\text { Jun. }}$} & \multirow{2}{*}{$\frac{2002}{\text { Jun. }}$} & \multirow{2}{*}{$\frac{2003}{\text { Jun. }}$} & \multirow{2}{*}{$\frac{2004}{\text { Jun. }}$} & \multirow{2}{*}{$\frac{2005}{\text { Jun. }}$} & \multicolumn{2}{|c|}{2006} & \multirow{2}{*}{$\frac{2007}{\text { Feb. }}$} \\
\hline & & & & & & Jun. & Dec. & \\
\hline \multicolumn{9}{|l|}{ Assets } \\
\hline Reserves & 2,535 & 3,812 & 4,864 & 4,922 & 5,364 & 8,964 & 7,615 & 8,561 \\
\hline Cash reserve ratio (CRR) & 641 & 672 & 1,821 & 1,538 & 1,257 & 1,959 & 1,756 & 1,849 \\
\hline Cash & 71 & 90 & 63 & 88 & 77 & 116 & 114 & 190 \\
\hline Excess reserves & 1,823 & 3,050 & 2,980 & 3,296 & 4,029 & 6,889 & 5,745 & 6,523 \\
\hline RMA bills & 356 & 771 & 390 & 149 & 199 & 83 & 33 & 33 \\
\hline Reserve repurchase & 500 & 0 & 0 & 0 & 0 & 0 & 0 & 0 \\
\hline Foreign assets & 2,916 & 2,885 & 3,613 & 3,430 & 2,009 & 2,329 & 4,320 & 2,479 \\
\hline Rupee & 2,150 & 1,981 & 1,756 & 2,001 & 1,087 & 955 & 3,136 & 945 \\
\hline Other & 767 & 904 & 1,857 & 1,429 & 922 & 1,374 & 1,184 & 1,534 \\
\hline Claims on government & 678 & 267 & 1,538 & 700 & 1,083 & 0 & 0 & 0 \\
\hline Claims on public enterprises & 333 & 292 & 257 & 268 & 693 & 631 & 634 & 598 \\
\hline Claims on joint enterprises & 113 & 115 & 120 & 159 & 132 & 113 & 135 & 395 \\
\hline Claims on private sector & 949 & 1,143 & 1,532 & 1,871 & 2,190 & 2,992 & 3,660 & 3,474 \\
\hline \multicolumn{9}{|l|}{ Liabilities } \\
\hline Demand deposits & 2,245 & 2,604 & 3,864 & 4,569 & 4,926 & 5,081 & 5,819 & 5,563 \\
\hline Current & 1,196 & 1,330 & 2,354 & 2,866 & 2,881 & 2,704 & 3,364 & 3,218 \\
\hline Savings & 1,049 & 1,275 & 1,510 & 1,703 & 2,045 & 2,377 & 2,455 & 2,345 \\
\hline Time and foreign currency deposits & 2,818 & 3,393 & 4,695 & 3,770 & 4,637 & 6,531 & 5,543 & 6,076 \\
\hline Of which: convertible currency & 201 & 257 & 1,159 & 561 & 337 & 458 & 411 & 824 \\
\hline Government deposits 1/ & 672 & 602 & 870 & 901 & 1,111 & 1,867 & 2,087 & 1,292 \\
\hline Capital account & 514 & 699 & 854 & 1,011 & 1,151 & 1,225 & 1,354 & 1,351 \\
\hline Other items (net) & 2,952 & 2,758 & 2,031 & 1,247 & 78 & 964 & 2,128 & 1,790 \\
\hline
\end{tabular}

Source: Data provided by the Bhutanese authorities.

$1 /$ Includes deposits of public enterprises and off-budgetary entities. 
Table 20. Bhutan: Assets and Liabilities of the Bhutan National Bank, 2001-2007

(In millions of ngultrum)

\begin{tabular}{|c|c|c|c|c|c|c|c|c|}
\hline & \multirow{2}{*}{$\frac{2001}{\text { Jun. }}$} & \multirow{2}{*}{$\frac{2002}{\text { Jun. }}$} & \multirow{2}{*}{$\frac{2003}{\text { Jun. }}$} & \multirow{2}{*}{$\frac{2004}{\text { Jun. }}$} & \multirow{2}{*}{$\frac{2005}{\text { Jun. }}$} & \multicolumn{2}{|c|}{2006} & \multirow{2}{*}{$\frac{2007}{\text { Feb. }}$} \\
\hline & & & & & & Jun. & $\overline{\text { Dec. }}$ & \\
\hline \multicolumn{9}{|l|}{ Assets } \\
\hline Reserves & 619 & 418 & 1,300 & 1,953 & 1,037 & 1,660 & 2,178 & 1,945 \\
\hline Cash reserve ratio & 332 & 358 & 980 & 673 & 767 & 903 & 1,106 & 1,116 \\
\hline Cash & 6 & 4 & 3 & 5 & 30 & 41 & 32 & 42 \\
\hline Excess reserves & 281 & 56 & 317 & 1,274 & 240 & 716 & 1,041 & 788 \\
\hline RMA bills & 48 & 129 & 304 & 50 & 50 & 83 & 33 & 33 \\
\hline Foreign assets & 2,024 & 2,020 & 1,572 & 889 & 881 & 1,474 & 1,708 & 1,947 \\
\hline Rupee & 1,328 & 1,064 & 732 & 552 & 438 & 693 & 449 & 489 \\
\hline Other & 696 & 956 & 840 & 337 & 443 & 781 & 1,259 & 1,458 \\
\hline Claims on government & 0 & 120 & 120 & 570 & 867 & 0 & 0 & 0 \\
\hline Claims on public enterprises & 0 & 0 & 0 & 527 & 583 & 647 & 635 & 636 \\
\hline Claims on joint enterprises & 7 & 7 & 8 & 8 & 8 & 8 & 8 & 8 \\
\hline Claims on private sector & 1,070 & 1,466 & 2,007 & 2,732 & 3,316 & 4,347 & 4,988 & 5,259 \\
\hline \multicolumn{9}{|l|}{ Liabilities } \\
\hline Demand deposits & 609 & 709 & 1,231 & 1,153 & 1,216 & 1,381 & 1,757 & 1,576 \\
\hline Time and foreign currency deposits & 1,923 & 2,409 & 2,766 & 3,325 & 3,334 & 4,882 & 5,102 & 5,557 \\
\hline Government deposits & 681 & 542 & 780 & 859 & 850 & 855 & 1,601 & 1,682 \\
\hline Capital account & 284 & 327 & 346 & 752 & 792 & 924 & 919 & 927 \\
\hline Other items (net) & 271 & 173 & 187 & 111 & 645 & 179 & 174 & 91 \\
\hline
\end{tabular}

Source: Data provided by the Bhutanese authorities. 
Table 21. Bhutan: Assets and Liabilities of the Royal Insurance Corporation of Bhutan, 2001-2007

(In millions of ngultrum)

\begin{tabular}{|c|c|c|c|c|c|c|c|c|}
\hline & \multirow{2}{*}{$\frac{2001}{\text { Jun. }}$} & \multirow{2}{*}{$\frac{2002}{\text { Jun. }}$} & \multirow{2}{*}{$\frac{2003}{\text { Jun. }}$} & \multirow{2}{*}{$\frac{2004}{\text { Jun. }}$} & \multirow{2}{*}{$\frac{2005}{\text { Jun. }}$} & \multicolumn{2}{|c|}{2006} & \multirow{2}{*}{$\frac{2007}{\text { Feb. }}$} \\
\hline & & & & & & $\overline{\text { Jun. }}$ & $\overline{\text { Dec. }}$ & \\
\hline \multicolumn{9}{|l|}{ Assets } \\
\hline Reserves $1 /$ & 52 & 39 & 92 & 103 & 42 & 66 & 71 & 79 \\
\hline Foreign assets & 51 & 56 & 9 & 4 & 7 & 12 & 11 & 15 \\
\hline Claims on public enterprises & 17 & 17 & 18 & 25 & 19 & 15 & 18 & 21 \\
\hline Claims on private sector & 907 & 1,075 & 1,184 & 1,307 & 1,487 & 1,571 & 1,612 & 1,628 \\
\hline Claims on deposit money banks & 0 & 0 & 55 & 20 & 8 & 68 & 58 & 63 \\
\hline \multicolumn{9}{|l|}{ Liabilities } \\
\hline Insurance reserve funds & 0 & 0 & 0 & 0 & 0 & 0 & 0 & 0 \\
\hline Life insurance fund & 50 & 44 & 57 & 79 & 102 & 139 & 154 & 162 \\
\hline Group insurance fund & 134 & 156 & 186 & 200 & 221 & 235 & 254 & 119 \\
\hline Provident Fund & 682 & 418.6 & 56 & 70 & 85 & 107 & 118 & 126 \\
\hline Credit from DMBs & 260 & 675 & 674 & 549 & 160 & 194 & 172 & 172 \\
\hline Capital accounts & 156 & 187 & 247 & 276 & 351 & 417 & 445 & 434 \\
\hline Other items (net) & -254 & -293 & 139 & 285 & 247 & 293 & 330 & 497 \\
\hline
\end{tabular}

Source: Data provided by the Bhutanese authorities.

1/ Includes deposits with the Bank of Bhutan. 
Table 22. Bhutan: Assets and Liabilities of the Bhutan Development Finance Corporation, 2001-2007

(In millions of ngultrum)

\begin{tabular}{|c|c|c|c|c|c|c|c|c|}
\hline & 2001 & 2002 & 2003 & 2004 & 2005 & \multicolumn{2}{|c|}{2006} & 2007 \\
\hline & $\overline{\text { Jun. }}$ & $\overline{\text { Jun. }}$ & Jun. & $\overline{\text { Jun. }}$ & $\overline{\text { Jun. }}$ & Jun. & $\overline{\text { Dec. }}$ & Feb. \\
\hline \multicolumn{9}{|l|}{ Assets } \\
\hline Reserves 1/ & 19 & 23 & 89 & 29 & 63 & 195 & 131 & 169 \\
\hline Claims on private sector $2 /$ & 587 & 819 & 1,092 & 1,191 & 1275 & 1,429 & 1,572 & 1,624 \\
\hline Claims on other banks & 107 & 15 & 0 & 10 & 10 & 80 & 80 & 0 \\
\hline Claims on government corporations & 1 & 1 & 1 & 1 & 0 & 0 & 0 & 0 \\
\hline \multicolumn{9}{|l|}{ Liabilities } \\
\hline Foreign liabilities & 228 & 304 & 343 & 332 & 312.5 & 289 & 279 & 272 \\
\hline Credit from RMA & 0 & 0 & 0 & 0 & 0 & 0 & 0 & 0 \\
\hline Credit from DMBs & 0 & 0 & 200 & 94 & 86 & 378 & 375 & 375 \\
\hline Credit from other NMFIs & 0 & 0 & 0 & 95 & 165 & 155 & 150 & 150 \\
\hline Grants & 50 & 50 & 50 & 50 & 50 & 50 & 50 & 50 \\
\hline Capital account & 309 & 356 & 393 & 448 & 513 & 598 & 694 & 699 \\
\hline Other items (net) & 127 & 148 & 196 & 213 & 252 & 273 & 272 & 287 \\
\hline
\end{tabular}

Source: Data provided by the Bhutanese authorities.

1/ Includes deposits with Bank of Bhutan.

$2 /$ Includes small amounts of investments in shares of public enterprises. 
Table 23. Bhutan: Financial Sector Investment by Sector of Economic Activity, 2001-2006

(In millions of ngultrum)

\begin{tabular}{|c|c|c|c|c|c|c|}
\hline & $\begin{array}{c}2001 \\
\text { Jun. }\end{array}$ & $\begin{array}{c}2002 \\
\text { Jun. }\end{array}$ & $\begin{array}{c}2003 \\
\text { Jun. }\end{array}$ & $\begin{array}{c}2004 \\
\text { Jun. }\end{array}$ & $\begin{array}{c}2005 \\
\text { Jun. }\end{array}$ & $\begin{array}{c}2006 \\
\text { Jun. }\end{array}$ \\
\hline Agriculture & 202 & 230 & 247 & 222 & 230 & 238 \\
\hline Bank of Bhutan & 3 & 6 & 6 & 4 & 1 & 1 \\
\hline Royal Insurance Corporation of Bhutan & 1 & 0 & 0 & 2 & 2 & 2 \\
\hline Bhutan Development Finance Corporation & 198 & 223 & 241 & 216 & 227 & 236 \\
\hline Bhutan National Bank & -- & -- & -- & -- & 0 & 0 \\
\hline Manufacturing & 785 & 974 & 1,290 & 1,485 & 1,440 & 2,022 \\
\hline Bank of Bhutan & 222 & 254 & 350 & 499 & 524 & 855 \\
\hline Royal Insurance Corporation of Bhutan & 203 & 257 & 281 & 239 & 109 & 142 \\
\hline Bhutan Development Finance Corporation & 138 & 181 & 211 & 204 & 226 & 263 \\
\hline Bhutan National Bank & 222 & 283 & 449 & 543 & 582 & 762 \\
\hline Building and construction & 719 & 1,113 & 1,641 & 2,176 & 3,126 & 3,938 \\
\hline Bank of Bhutan & 142 & 232 & 342 & 448 & 633 & 806 \\
\hline Royal Insurance Corporation of Bhutan & 274 & 332 & 394 & 440 & 661 & 686 \\
\hline Bhutan Development Finance Corporation & 41 & 141 & 296 & 355 & 419 & 491 \\
\hline Bhutan National Bank & 262 & 408 & 609 & 933 & 1,413 & 1,955 \\
\hline Trade and commerce & 1,644 & 1,262 & 960 & 1,395 & 1,466 & 1,767 \\
\hline Bank of Bhutan & 1,163 & 578 & 338 & 479 & 567 & 668 \\
\hline Royal Insurance Corporation of Bhutan & 118 & 147 & 318 & 489 & 391 & 408 \\
\hline Bhutan Development Finance Corporation & 170 & 256 & 82 & 116 & 58 & 88 \\
\hline Bhutan National Bank & 193 & 281 & 223 & 312 & 451 & 603 \\
\hline Transport & 712 & 730 & 796 & 772 & 812 & 829 \\
\hline Bank of Bhutan & 404 & 411 & 463 & 448 & 437 & 430 \\
\hline Royal Insurance Corporation of Bhutan & 161 & 152 & 120 & 68 & 87 & 91 \\
\hline Bhutan Development Finance Corporation & 24 & 13 & 11 & 12 & 27 & 30 \\
\hline Bhutan National Bank & 123 & 154 & 202 & 244 & 261 & 278 \\
\hline Personal and other loans $1 /$ & 497 & 599 & 2,507 & 1,439 & 3,547 & 2,505 \\
\hline Bank of Bhutan & 90 & 91 & 1,684 & 437 & 1,495 & 1,059 \\
\hline Royal Insurance Corporation of Bhutan & 124 & 161 & 46 & 44 & 219 & 218 \\
\hline Bhutan Development Finance Corporation & 15 & 5 & 250 & 266 & 333 & 334 \\
\hline Bhutan National Bank & 268 & 341 & 527 & 692 & 1,500 & 894 \\
\hline Total & 4,558 & 4,907 & 7,441 & 7,489 & 10,620 & 11,298 \\
\hline
\end{tabular}

Source: Data provided by the Bhutanese authorities.

$1 /$ Includes personal loans, government employee loans, and loans to the services and tourism sectors. 
Table 24. Bhutan: Royal Monetary Authority of Bhutan Bills Auctions, 2002-2007 1/

\begin{tabular}{|c|c|c|c|}
\hline Auction Date & $\begin{array}{l}\text { Bids Received } \\
\text { (Nu million) }\end{array}$ & $\begin{array}{l}\text { Bids Accepted } \\
\text { (Nu million) }\end{array}$ & $\begin{array}{l}\text { Discount Rate } \\
\text { (percent) }\end{array}$ \\
\hline $1 / 29 / 02$ & 770 & 650 & 5.00 \\
\hline $3 / 4 / 02$ & 110 & 110 & 5.00 \\
\hline $3 / 18 / 02$ & 150 & 150 & 5.00 \\
\hline $4 / 29 / 02$ & 650 & 650 & 4.50 \\
\hline $6 / 3 / 02$ & 110 & 110 & 4.50 \\
\hline $6 / 18 / 02$ & 150 & 150 & 4.50 \\
\hline $7 / 29 / 02$ & 665 & 665 & 4.50 \\
\hline $9 / 2 / 02$ & 110 & 110 & 4.50 \\
\hline $9 / 19 / 02$ & 150 & 150 & 4.00 \\
\hline $10 / 29 / 02$ & 500 & 500 & 4.00 \\
\hline $11 / 2 / 02$ & 300 & 300 & 4.00 \\
\hline $11 / 19 / 02$ & 450 & 300 & 4.00 \\
\hline $1 / 27 / 03$ & 500 & 500 & 4.00 \\
\hline $3 / 5 / 03$ & 400 & 200 & 4.00 \\
\hline $3 / 20 / 03$ & 400 & 200 & 4.00 \\
\hline $4 / 30 / 03$ & 600 & 300 & 4.00 \\
\hline $5 / 5 / 03$ & 275 & 200 & 3.50 \\
\hline $6 / 25 / 03$ & 400 & 200 & 3.50 \\
\hline $7 / 30 / 03$ & 350 & 200 & 3.50 \\
\hline $8 / 27 / 03$ & 400 & 200 & 3.50 \\
\hline $9 / 24 / 03$ & 200 & 100 & 3.50 \\
\hline $11 / 30 / 03$ & 200 & 100 & 3.50 \\
\hline $3 / 31 / 04$ & 200 & 100 & 3.50 \\
\hline $4 / 28 / 04$ & 100 & 100 & 3.50 \\
\hline $7 / 28 / 04$ & 100 & 100 & 3.50 \\
\hline $8 / 25 / 04$ & 100 & 100 & 3.50 \\
\hline $10 / 27 / 04$ & 100 & 100 & 3.50 \\
\hline $11 / 24 / 04$ & 100 & 100 & 3.50 \\
\hline $1 / 26 / 05$ & 100 & 100 & 3.50 \\
\hline $2 / 23 / 05$ & 100 & 100 & 3.50 \\
\hline $5 / 25 / 05$ & 100 & 100 & 3.50 \\
\hline $6 / 29 / 05$ & 100 & 100 & 3.50 \\
\hline $9 / 28 / 05$ & 100 & 100 & 3.50 \\
\hline $11 / 30 / 05$ & 100 & 100 & 3.50 \\
\hline $2 / 22 / 06$ & 100 & 100 & 3.50 \\
\hline $2 / 22 / 06$ & 100 & 100 & 3.50 \\
\hline $4 / 26 / 06$ & 100 & 100 & 3.50 \\
\hline $6 / 28 / 06$ & 100 & 100 & 3.50 \\
\hline $8 / 30 / 06$ & 100 & 100 & 3.50 \\
\hline $10 / 25 / 06$ & 100 & 100 & 3.50 \\
\hline $1 / 31 / 07$ & 100 & 100 & 3.50 \\
\hline $4 / 26 / 07$ & 100 & 100 & 3.50 \\
\hline $6 / 27 / 07$ & 100 & 100 & 3.50 \\
\hline
\end{tabular}

Source: Data provided by the Bhutanese authorities.

$1 /$ The RMA bills carry a maturity of 91 days. 
Table 25. Bhutan: Structure of Interest Rates, 2001-2006

(In percent per annum, end of period)

\begin{tabular}{|c|c|c|c|c|c|c|}
\hline & $\frac{2001}{\text { Jun. }}$ & $\frac{2002}{\text { Jun. }}$ & $\frac{2003}{\text { Jun. }}$ & $\frac{2004}{\text { Jun. }}$ & $\frac{2005}{\text { Jun. }}$ & $\frac{2006}{\text { Jun. }}$ \\
\hline \multicolumn{7}{|l|}{ Deposit rates } \\
\hline \multicolumn{7}{|l|}{ Bank of Bhutan } \\
\hline Savings & 5.0 & 5.0 & 5.0 & 4.5 & 4.5 & 4.5 \\
\hline \multicolumn{7}{|l|}{ Fixed } \\
\hline $3-6$ months & 7.0 & 7.0 & 5.5 & 4.5 & 4.5 & 4.5 \\
\hline 6-9 months & 7.0 & 7.0 & 5.5 & 4.5 & 4.5 & 4.5 \\
\hline 9-12 months & 7.0 & 7.0 & 5.5 & 4.5 & 4.5 & 4.5 \\
\hline $1-3$ years & 9.0 & 9.0 & 7.5 & 6.0 & 6.0 & 6.0 \\
\hline $3-5$ years & 10.0 & 10.0 & 8.5 & 7.0 & 7.0 & 7.0 \\
\hline Over 5 years & 10.0 & 10.0 & 8.5 & 7.0 & 7.0 & 7.0 \\
\hline \multicolumn{7}{|l|}{ Bhutan National Bank } \\
\hline Savings & 7.0 & 6.0 & 5.0 & 5.0 & 4.5 & 4.5 \\
\hline \multicolumn{7}{|l|}{ Fixed } \\
\hline 3-6 months & 8.0 & 7.0 & 6.0 & 5.5 & 4.5 & 4.5 \\
\hline 6-9 months & 8.0 & 7.0 & 6.0 & 5.5 & 4.5 & 4.5 \\
\hline 9-12 months & 8.0 & 7.0 & 6.0 & 5.5 & 4.5 & 4.5 \\
\hline $1-3$ years & 10.0 & 9.0 & 7.0 & $6.0-6.5$ & 6.5 & 6.5 \\
\hline $3-5$ years & 11.0 & 10.0 & 8.0 & 7.0 & 7.0 & 7.0 \\
\hline Over 5 years & 11.0 & 10.0 & 8.0 & 7.0 & 7.0 & 7.0 \\
\hline \multicolumn{7}{|l|}{ Lending rates } \\
\hline Commerce & $15.0-15.5$ & 15.0 & 15.0 & 15.0 & 13.8 & 13.8 \\
\hline Exports & $13.0-15.5$ & $13.0-15.0$ & $13.0-15.0$ & $13.0-15.0$ & 13.0 & 13.0 \\
\hline Transport & $13.0-16.0$ & $13.0-16.0$ & $13.0-16.0$ & $12.0-15.0$ & $13.0-14.0$ & $13.0-14.0$ \\
\hline Agriculture & 13.0 & $12.0-15.0$ & $13.0-15.0$ & $13.0-15.0$ & $13.0-15.0$ & $13.0-15.0$ \\
\hline Industry and manufacturing & $13.0-13.5$ & $12.0-13.0$ & $12.0-13.0$ & $12.0-13.0$ & $12.0-13.0$ & $12.0-13.0$ \\
\hline $\begin{array}{l}\text { Service industries, } \\
\text { including tourism }\end{array}$ & 13.0 & $12.0-13.0$ & $12.0-13.0$ & $12.0-15.0$ & $10.0-13.0$ & $10.0-13.0$ \\
\hline Housing & 14.0 & 13.0 & 13.0 & $10.0-13.0$ & $10.0-13.0$ & $10.0-13.0$ \\
\hline Miscellaneous & $15.0-16.0$ & 15.0 & 16.0 & 16.0 & 15.0 & 15.0 \\
\hline \multicolumn{7}{|l|}{ Memorandum items: } \\
\hline Deposit rates (India) 1/ & 8.0 & 8.0 & 5.5 & 5.3 & 5.8 & 6.6 \\
\hline Lending rates (India) 2/ & 12.0 & 12.0 & $10.5-11.5$ & $10.25-11.0$ & $10.25-10.75$ & $10.75-11.25$ \\
\hline
\end{tabular}

Sources: Data provided by the Bhutanese authorities; and CEIC Data Company Ltd.

$1 /$ Average deposit rate of major banks (one-year maturity).

2/ Prime lending rate. 
Table 26. Bhutan: Balance of Payments Summary, 2001/02-2005/2006

\begin{tabular}{|c|c|c|c|c|c|}
\hline & $2001 / 02$ & $2002 / 03$ & $2003 / 04$ & $2004 / 05$ & $\frac{2005 / 06}{\text { Prov. }}$ \\
\hline Trade balance & -99 & -93 & -105 & -248 & -123 \\
\hline Exports, f.o.b. & 104 & 113 & 158 & 212 & 312 \\
\hline Imports, c.i.f. & -203 & -206 & -263 & -461 & -435 \\
\hline Services (net) & -5 & -17 & -8 & -11 & -1 \\
\hline Income (net) & -5 & -11 & -16 & -17 & -11 \\
\hline Current transfers & 44 & 38 & 56 & 59 & 106 \\
\hline India & 32 & 11 & 31 & 23 & 60 \\
\hline Other & 12 & 27 & 25 & 36 & 46 \\
\hline Of which: grant receipts & 79 & 73 & 94 & 120 & 176 \\
\hline Current account (including grants) & -65 & -84 & -73 & -217 & -29 \\
\hline Capital and financial account & 103 & 218 & 185 & 215 & 144 \\
\hline Capital transfer & 42 & 121 & 103 & 93 & 60 \\
\hline Foreign direct investment & 2 & 2 & 3 & 9 & 6 \\
\hline Portfolio investment & 0 & 0 & 0 & 0 & 0 \\
\hline Total loans (net) & 59 & 94 & 103 & 78 & 78 \\
\hline Errors and omissions & -12 & -80 & -104 & -18 & -4 \\
\hline Overall balance & 26 & 55 & 8 & -21 & 111 \\
\hline \multicolumn{6}{|l|}{ Financing } \\
\hline Change in net reserves (increase $=-$ ) & -26 & -55 & -8 & 21 & -111 \\
\hline \multicolumn{6}{|l|}{ Memorandum items: } \\
\hline Gross official reserves & 315 & 373 & 383 & 367 & 479 \\
\hline (In months of imports of goods) & 18.3 & 17.1 & 10.0 & 10.1 & 11.3 \\
\hline Ngultrum per US\$ (period average) & 48.2 & 47.9 & 45.4 & 44.6 & 44.7 \\
\hline
\end{tabular}

Source: Data provided by the Bhutanese authorities. 
Table 27. Bhutan: Balance of Payments with India, 2001/02-2005/06

\begin{tabular}{|c|c|c|c|c|c|c|}
\hline & $2000 / 01$ & $2001 / 02$ & $2002 / 03$ & $2003 / 04$ & $2004 / 05$ & $\frac{2005 / 06}{\text { Prov. }}$ \\
\hline & \multicolumn{6}{|c|}{ (In millions of U.S. dollars) } \\
\hline Trade balance & -40 & -64 & -82 & -84 & -81 & -71 \\
\hline Exports, f.o.b. & 94 & 98 & 106 & 149 & 194 & 237 \\
\hline Of which: Chukha exports & 43 & 42 & 41 & 51 & 47 & 67 \\
\hline Imports, c.i.f. & -134 & -162 & -188 & -233 & -275 & -308 \\
\hline Service balance & -7 & -6 & -9 & -4 & -20 & -17 \\
\hline Travel and other service receipts & 13 & 14 & 12 & 17 & 19 & 27 \\
\hline Travel and other service payments & -21 & -20 & -21 & -21 & -39 & -44 \\
\hline Income & -8 & -10 & -14 & -18 & -22 & -19 \\
\hline Interest and other income receipts & 5 & 4 & 8 & 5 & 4 & 6 \\
\hline Interest and other income payments & -14 & -14 & -21 & -23 & -26 & -25 \\
\hline Transfers & 31 & 32 & 11 & 31 & 23 & 60 \\
\hline Grants to government (budgetary) & 55 & 53 & 18 & 50 & 59 & 86 \\
\hline Excise duty refund & 0 & 8 & 12 & 1 & 7 & 17 \\
\hline Transfer payments & -26 & -28 & -20 & -20 & -43 & -43 \\
\hline Current account balance & -24 & -48 & -93 & -75 & -99 & -47 \\
\hline Capital and financial account & 70 & 81 & 186 & 175 & 147 & 112 \\
\hline Capital transfer & 33 & 42 & 121 & 103 & 93 & 60 \\
\hline Foreign direct investment & 0 & 0 & 0 & 0 & 0 & 0 \\
\hline Portfolio investments & 0 & 0 & 0 & 0 & 0 & 0 \\
\hline Loans (net) & 37 & 39 & 65 & 72 & 53 & 52 \\
\hline Receipts & 39 & 40 & 67 & 74 & 60 & 58 \\
\hline \multicolumn{7}{|l|}{ Of which: } \\
\hline Concessional & 39 & 40 & 67 & 74 & 60 & 58 \\
\hline Nonconcessional & 0 & 0 & 0 & 0 & 0 & 0 \\
\hline Payments & 2 & 2 & 2 & 2 & 6 & 6 \\
\hline \multicolumn{7}{|l|}{ Of which: } \\
\hline Concessional & 2 & 2 & 2 & 2 & 6 & 6 \\
\hline Nonconcessional & 0 & 0 & 0 & 0 & 0 & 0 \\
\hline Errors and omissions & -36 & -30 & -100 & -76 & -65 & -76 \\
\hline Overall balance & 10 & 2 & -7 & 23 & -18 & -10 \\
\hline \multicolumn{7}{|l|}{ Financing } \\
\hline \multirow[t]{2}{*}{ Change in net reserves (increase $=-$ ) } & -10 & -2 & 7 & -23 & 18 & 10 \\
\hline & \multicolumn{6}{|c|}{ (In percent of GDP) } \\
\hline \multicolumn{7}{|l|}{ Memorandum items: } \\
\hline Exports & 20.4 & 19.1 & 18.4 & 22.0 & 25.1 & 27.0 \\
\hline Imports & 29.0 & 31.7 & 32.4 & 34.5 & 35.6 & 35.1 \\
\hline Current account balance & -5.2 & -9.5 & -16.1 & -11.1 & -12.9 & -5.3 \\
\hline
\end{tabular}

Source: Data provided by the Bhutanese authorities. 
Table 28. Bhutan: Balance of Payments with Third Countries, 2001/02-2005/06

\begin{tabular}{|c|c|c|c|c|c|c|}
\hline & $2000 / 01$ & $2001 / 02$ & $2002 / 03$ & $2003 / 04$ & $2004 / 05$ & $\begin{array}{r}2005 / 06 \\
\text { Prov. }\end{array}$ \\
\hline & \multicolumn{6}{|c|}{ (In millions of U.S. dollars) } \\
\hline Trade balance & -30 & -35 & -12 & -21 & -167 & -52 \\
\hline Exports, f.o.b. & 5 & 6 & 6 & 9 & 18 & 75 \\
\hline Imports, c.i.f. & -35 & -42 & -18 & -29 & -186 & -127 \\
\hline Service balance & 3 & 2 & -8 & -4 & 9 & 16 \\
\hline Travel and other service receipts & 18 & 15 & 12 & 14 & 27 & 33 \\
\hline Travel and other service payments & -14 & -14 & -20 & -18 & -18 & -18 \\
\hline Income & 11 & 5 & 2 & 1 & 5 & 8 \\
\hline Interest and other income receipts & 12 & 7 & 4 & 4 & 8 & 12 \\
\hline Interest and other income payments & -1 & -2 & -2 & -3 & -3 & -4 \\
\hline Transfers & 14 & 12 & 27 & 25 & 36 & 46 \\
\hline Grants to government (budgetary) & 25 & 26 & 55 & 44 & 54 & 73 \\
\hline Private transfer receipts (including NGOs) & 5 & 5 & 6 & 12 & 13 & 12 \\
\hline Transfer payments & -16 & -20 & -34 & -31 & -31 & -39 \\
\hline Current account (including grants) & -2 & -17 & 10 & 2 & -118 & 18 \\
\hline Capital and financial account & -6 & 22 & 32 & 10 & 68 & 31 \\
\hline Foreign direct investment & 0 & 2 & 2 & 3 & 9 & 6 \\
\hline Portfolio investments & -19 & 0 & 0 & 0 & 0 & 0 \\
\hline Loans (net) & 13 & 20 & 29 & 31 & 24 & 26 \\
\hline Receipts & 16 & 23 & 33 & 34 & 27 & 29 \\
\hline Payments & 3 & 3 & 3 & 3 & 3 & 4 \\
\hline Errors and omissions & 4 & 18 & 20 & -27 & 47 & 72 \\
\hline Overall balance & -5 & 23 & 61 & -15 & -3 & 121 \\
\hline \multicolumn{7}{|l|}{ Financing } \\
\hline \multirow[t]{2}{*}{ Change in net reserves (increase $=-$ ) } & 5 & -23 & -61 & 15 & 3 & -121 \\
\hline & \multicolumn{6}{|c|}{ (In percent of GDP) } \\
\hline \multicolumn{7}{|l|}{ Memorandum items: } \\
\hline Exports & 1.1 & 1.2 & 1.1 & 1.3 & 2.3 & 8.5 \\
\hline Imports & 7.7 & 8.2 & 3.2 & 4.3 & 24.1 & 14.4 \\
\hline Current account & -0.5 & -3.3 & 1.7 & 0.3 & -15.2 & 2.0 \\
\hline
\end{tabular}

Source: Data provided by the Bhutanese authorities. 
Table 29. Bhutan: Exports to India, 2001-2006

\begin{tabular}{|c|c|c|c|c|c|c|}
\hline & 2001 & 2002 & 2003 & 2004 & 2005 & 2006 \\
\hline & \multicolumn{6}{|c|}{ (In millions of ngultrum) } \\
\hline Animal products & 0 & 0 & 0 & 0 & 1 & 9 \\
\hline Vegetables, fruits, nuts, coffee, tea, and spices & 280 & 391 & 257 & 286 & 243 & 277 \\
\hline Vegetables fats and oil & 0 & 0 & 0 & 0 & 224 & 1,448 \\
\hline Prepared foodstuffs & 218 & 209 & 391 & 408 & 389 & 414 \\
\hline Mineral products & 609 & 534 & 588 & 674 & 983 & 1,587 \\
\hline Electricity & 2,073 & 2,347 & 2,604 & 2,712 & 3,440 & 4,982 \\
\hline Plastic and rubber products & 55 & 84 & 199 & 271 & 293 & 247 \\
\hline Raw hides and skins & 3 & 4 & 4 & 2 & 1 & 2 \\
\hline Wood and wood products & 241 & 177 & 215 & 280 & 310 & 254 \\
\hline Wood pulp products & 1 & 0 & 0 & 2 & 4 & 4 \\
\hline Textiles & 1 & 13 & 113 & 536 & 787 & 476 \\
\hline Footwear, headgear and clothing accessories & 0 & 0 & 0 & 0 & 0 & 0 \\
\hline Stone, plaster, cement and asbestos products & 14 & 22 & 18 & 24 & 15 & 25 \\
\hline Base metals and base metal products & 595 & 628 & 882 & 1,737 & 2,491 & 4,098 \\
\hline Machinery and mechanical appliances & 0 & 39 & 4 & 73 & 34 & 52 \\
\hline Transport equipment & 0 & 3 & 0 & 15 & 16 & 1 \\
\hline Optical, photographic and measuring equipment & 0 & 4 & 2 & 1 & 0 & 0 \\
\hline Miscellaneous manufactured articles & 19 & 12 & 18 & 27 & 22 & 26 \\
\hline Product of chemical industries & 589 & 668 & 630 & 712 & 714 & 587 \\
\hline \multirow[t]{2}{*}{ Total } & 4,700 & 5,137 & 5,926 & 7,762 & 9,970 & 14,488 \\
\hline & \multicolumn{6}{|c|}{ (In percent of total) } \\
\hline Animal products & 0.0 & 0.0 & 0.0 & 0.0 & 0.0 & 0.1 \\
\hline Vegetables, fruits, nuts, coffee, tea, and spices & 6.0 & 7.6 & 4.3 & 3.7 & 2.4 & 1.9 \\
\hline Vegetables fats and oil & 0.0 & 0.0 & 0.0 & 0.0 & 2.3 & 10.0 \\
\hline Prepared foodstuffs & 4.6 & 4.1 & 6.6 & 5.3 & 3.9 & 2.9 \\
\hline Mineral products & 13.0 & 10.4 & 9.9 & 8.7 & 9.9 & 11.0 \\
\hline Electricity & 44.1 & 45.7 & 43.9 & 34.9 & 34.5 & 34.4 \\
\hline Plastic and rubber products & 1.2 & 1.6 & 3.4 & 3.5 & 2.9 & 1.7 \\
\hline Raw hides and skins & 0.1 & 0.1 & 0.1 & 0.0 & 0.0 & 0.0 \\
\hline Wood and wood products & 5.1 & 3.4 & 3.6 & 3.6 & 3.1 & 1.8 \\
\hline Wood pulp products & 0.0 & 0.0 & 0.0 & 0.0 & 0.0 & 0.0 \\
\hline Textiles & 0.0 & 0.3 & 1.9 & 6.9 & 7.9 & 3.3 \\
\hline Footwear, headgear and clothing accessories & 0.0 & 0.0 & 0.0 & 0.0 & 0.0 & 0.0 \\
\hline Stone, plaster, cement and asbestos products & 0.3 & 0.4 & 0.3 & 0.3 & 0.1 & 0.2 \\
\hline Base metals and base metal products & 12.7 & 12.2 & 14.9 & 22.4 & 25.0 & 28.3 \\
\hline Machinery and mechanical appliances & 0.0 & 0.8 & 0.1 & 0.9 & 0.3 & 0.4 \\
\hline Transport equipment & 0.0 & 0.1 & 0.0 & 0.2 & 0.2 & 0.0 \\
\hline Optical, photographic and measuring equipment & 0.0 & 0.1 & 0.0 & 0.0 & 0.0 & 0.0 \\
\hline Miscellaneous manufactured articles & 0.4 & 0.2 & 0.3 & 0.3 & 0.2 & 0.2 \\
\hline Product of chemical industries & 12.5 & 13.0 & 10.6 & 9.2 & 7.2 & 4.1 \\
\hline Total & 100 & 100 & 100 & 100 & 100 & 100 \\
\hline
\end{tabular}

Source: Department of Revenue and Customs. 
Table 30. Bhutan: Imports from India, 2001-2006

\begin{tabular}{|c|c|c|c|c|c|c|}
\hline & 2001 & 2002 & 2003 & 2004 & 2005 & 2006 \\
\hline & \multicolumn{6}{|c|}{ (In millions of ngultrum) } \\
\hline Animal products & 271 & 318 & 369 & 436 & 568 & 629 \\
\hline Cereals, vegetables, fruits, nuts, coffee, tea, and spices & 556 & 608 & 745 & 646 & 725 & 840 \\
\hline Vegetables fats and oil & 201 & 221 & 175 & 165 & 230 & 312 \\
\hline Prepared foodstuffs & 504 & 546 & 574 & 624 & 752 & 766 \\
\hline Mineral products $1 /$ & 1,513 & 1,435 & 1,860 & 2,121 & 2,746 & 3,221 \\
\hline Products of chemical industries & 515 & 456 & 562 & 665 & 596 & 679 \\
\hline Plastics and rubber products & 158 & 179 & 262 & 372 & 368 & 458 \\
\hline Raw hides and skins & 5 & 5 & 4 & 8 & 6 & 5 \\
\hline Wood and wood products & 148 & 97 & 101 & 124 & 120 & 119 \\
\hline Wood pulp products & 151 & 145 & 180 & 217 & 233 & 257 \\
\hline Textiles & 169 & 181 & 152 & 176 & 172 & 185 \\
\hline Footwear, headgear and clothing accessories & 50 & 64 & 71 & 56 & 54 & 56 \\
\hline Stone, plaster, cement and asbestos products & 145 & 134 & 155 & 183 & 191 & 260 \\
\hline Precious or semi-precious metal products & 0 & 0 & 0 & 18 & 162 & 41 \\
\hline Base metals and base metal products & 969 & 928 & 1,442 & 1,965 & 2,507 & 2,003 \\
\hline Machinery and mechanical appliances & 1,014 & 1,528 & 2,786 & 1,671 & 2,324 & 2,273 \\
\hline Transport equipment & 455 & 563 & 559 & 571 & 549 & 639 \\
\hline Optical, photographic and measuring equipment & 88 & 96 & 201 & 69 & 386 & 186 \\
\hline Miscellaneous manufactured articles & 78 & 78 & 62 & 105 & 104 & 125 \\
\hline Works of art, antiques and special transactions & 0 & 1 & 0 & 0 & 0 & 0 \\
\hline \multirow[t]{2}{*}{ Total } & 6,989 & 7,581 & 10,260 & 10,194 & 12,795 & 13,054 \\
\hline & \multicolumn{6}{|c|}{ (In percent of total) } \\
\hline Animal products & 3.9 & 4.2 & 3.6 & 4.3 & 4.4 & 4.8 \\
\hline Cereals, vegetables, fruits, nuts, coffee, tea, and spices & 8.0 & 8.0 & 7.3 & 6.3 & 5.7 & 6.4 \\
\hline Vegetables fats and oil & 2.9 & 2.9 & 1.7 & 1.6 & 1.8 & 2.4 \\
\hline Prepared foodstuffs & 7.2 & 7.2 & 5.6 & 6.1 & 5.9 & 5.9 \\
\hline Mineral products $1 /$ & 21.6 & 18.9 & 18.1 & 20.8 & 21.5 & 24.7 \\
\hline Products of chemical industries & 7.4 & 6.0 & 5.5 & 6.5 & 4.7 & 5.2 \\
\hline Plastics and rubber products & 2.3 & 2.4 & 2.5 & 3.6 & 2.9 & 3.5 \\
\hline Raw hides and skins & 0.1 & 0.1 & 0.0 & 0.1 & 0.0 & 0.0 \\
\hline Wood and wood products & 2.1 & 1.3 & 1.0 & 1.2 & 0.9 & 0.9 \\
\hline Wood pulp products & 2.2 & 1.9 & 1.8 & 2.1 & 1.8 & 2.0 \\
\hline Textiles & 2.4 & 2.4 & 1.5 & 1.7 & 1.3 & 1.4 \\
\hline Footwear, headgear and clothing accessories & 0.7 & 0.8 & 0.7 & 0.6 & 0.4 & 0.4 \\
\hline Stone, plaster, cement and asbestos products & 2.1 & 1.8 & 1.5 & 1.8 & 1.5 & 2.0 \\
\hline Precious or semi-precious metal products & 0.0 & 0.0 & 0.0 & 0.2 & 1.3 & 0.3 \\
\hline Base metals and base metal products & 13.9 & 12.2 & 14.1 & 19.3 & 19.6 & 15.3 \\
\hline Machinery and mechanical appliances & 14.5 & 20.2 & 27.1 & 16.4 & 18.2 & 17.4 \\
\hline Transport equipment & 6.5 & 7.4 & 5.4 & 5.6 & 4.3 & 4.9 \\
\hline Optical, photographic and measuring equipment & 1.3 & 1.3 & 2.0 & 0.7 & 3.0 & 1.4 \\
\hline Miscellaneous manufactured articles & 1.1 & 1.0 & 0.6 & 1.0 & 0.8 & 1.0 \\
\hline Works of art, antiques and special transactions & 0.0 & 0.0 & 0.0 & 0.0 & 0.0 & 0.0 \\
\hline Total & 100 & 100 & 100 & 100 & 100 & 100 \\
\hline
\end{tabular}

Sources: Department of Revenue and Customs; and for electricity exports/imports, from respective power authorities.

1/ Data on electricity imports are already included under the category 'mineral products.' 
Table 31. Bhutan: Exports to Third Countries, 2001-2005

\begin{tabular}{|c|c|c|c|c|c|}
\hline & 2001 & 2002 & 2003 & 2004 & 2005 \\
\hline & \multicolumn{5}{|c|}{ (In millions of ngultrum) } \\
\hline Vegetables and fruits & 164 & 115 & 166 & 299 & 357 \\
\hline Processed food & 14 & 7 & 5 & 10 & 5 \\
\hline Mineral products & 92 & 139 & 81 & 142 & 261 \\
\hline Plastic products & 0 & 0 & 3 & 21 & 5 \\
\hline Photographic film and photographic materials & 0 & 0 & 0 & 0 & 0 \\
\hline Wood products & 1 & 7 & 2 & 4 & 1 \\
\hline Woodpile products & 8 & 2 & 0 & 0 & 29 \\
\hline Textiles & 5 & 11 & 0 & 1 & 0 \\
\hline Coins & 0 & 0 & 0 & 0 & 0 \\
\hline Base metals and base metal products & 0 & 3 & 0 & 12 & 0 \\
\hline Machinery & 0 & 57 & 0 & 6 & 619 \\
\hline Philatelic products & 0 & 0 & 0 & 0 & 0 \\
\hline Handicrafts products & 2 & 0 & 0 & 0 & 138 \\
\hline Household items and personal effects & 8 & 2 & 7 & 15 & 0 \\
\hline \multirow[t]{2}{*}{ Total } & 294 & 343 & 264 & 510 & 1,416 \\
\hline & \multicolumn{5}{|c|}{ (In percent of total) } \\
\hline Vegetables and fruits & 55.7 & 33.6 & 62.9 & 58.6 & 25.2 \\
\hline Processed food & 4.9 & 1.9 & 1.8 & 1.9 & 0.4 \\
\hline Mineral products & 31.3 & 40.7 & 30.8 & 27.9 & 18.4 \\
\hline Plastic products & 0.0 & 0.0 & 1.0 & 4.1 & 0.4 \\
\hline Wood products & 0.4 & 2.1 & 0.7 & 0.7 & 0.1 \\
\hline Woodpile products & 2.6 & 0.4 & 0.0 & 0.0 & 2.0 \\
\hline Textiles & 1.7 & 3.2 & 0.1 & 0.2 & 0.0 \\
\hline Base metals and base metal products & 0.0 & 0.8 & 0.0 & 2.4 & 0.0 \\
\hline Machinery & 0.0 & 16.6 & 0.1 & 1.2 & 43.7 \\
\hline Philatelic products & 0.0 & 0.0 & 0.0 & 0.0 & 0.0 \\
\hline Handicrafts products & 0.8 & 0.1 & 0.0 & 0.1 & 9.8 \\
\hline Household items and personal effects & 2.7 & 0.7 & 2.6 & 2.9 & 0.0 \\
\hline Total & 100 & 100 & 100 & 100 & 100 \\
\hline
\end{tabular}

Source: Department of Revenue and Customs. 
Table 32. Bhutan: Imports from Third Countries, 2001-2005

\begin{tabular}{|c|c|c|c|c|c|}
\hline & 2001 & 2002 & 2003 & 2004 & 2005 \\
\hline & \multicolumn{5}{|c|}{ (In millions of ngultrum) } \\
\hline Animal products & 7 & 8 & 8 & 1 & 2 \\
\hline Vegetables, fruits, nuts, coffee, cereals, seeds & 3 & 19 & 5 & 33 & 21 \\
\hline Vegetables fats and oil & 10 & 19 & 51 & 148 & 93 \\
\hline Whiskies and processed food & 77 & 60 & 32 & 154 & 151 \\
\hline Mineral oil and fuel & 1 & 32 & 1 & 106 & 2 \\
\hline Product of chemical industries & 19 & 26 & 26 & 55 & 97 \\
\hline Medicine and Pharmaceuticals & 24 & 11 & 12 & 23 & 39 \\
\hline Photographic film and materials & 2 & 2 & 0 & 13 & 3 \\
\hline Plastic and rubber products & 132 & 105 & 100 & 235 & 242 \\
\hline Wood products & 22 & 11 & 2 & 9 & 13 \\
\hline Wood pulp products & 21 & 10 & 22 & 55 & 44 \\
\hline Textiles & 60 & 81 & 99 & 522 & 538 \\
\hline Machinery, mechanical appliances, base metals and electronic items & 1,539 & 1,506 & 948 & 6,961 & 2,922 \\
\hline Ceramic and melamine products & 13 & 11 & 1 & 8 & 3 \\
\hline Trekking equipment, footwear and carpets & 13 & 13 & 9 & 48 & 18 \\
\hline Miscellaneous manufactured articles & 31 & 36 & 17 & 75 & 36 \\
\hline Precious and semi-precious metals & 1 & 0 & 3 & 0 & 14 \\
\hline Tobacco and cigarettes & 3 & 5 & 2 & 0 & 0 \\
\hline Personal effects & 21 & 16 & 0 & 0 & 0 \\
\hline \multirow[t]{2}{*}{ Total } & 2,001 & 1,974 & 1,338 & 8,446 & 4,240 \\
\hline & \multicolumn{5}{|c|}{ (In percent of total) } \\
\hline Animal products & 0.4 & 0.4 & 0.6 & 0.0 & 0.1 \\
\hline Vegetables, fruits, nuts, coffee, cereals, seeds & 0.2 & 1.0 & 0.4 & 0.4 & 0.5 \\
\hline Vegetables fats and oil & 0.5 & 1.0 & 3.8 & 1.7 & 2.2 \\
\hline Whiskies and processed food & 3.9 & 3.1 & 2.4 & 1.8 & 3.6 \\
\hline Mineral oil and fuel & 0.1 & 1.6 & 0.1 & 1.3 & 0.1 \\
\hline Product of chemical industries & 1.0 & 1.3 & 1.9 & 0.7 & 2.3 \\
\hline Medicine and Pharmaceuticals & 1.2 & 0.6 & 0.9 & 0.3 & 0.9 \\
\hline Photographic film and materials & 0.1 & 0.1 & 0.0 & 0.1 & 0.1 \\
\hline Plastic and rubber products & 6.6 & 5.3 & 7.5 & 2.8 & 5.7 \\
\hline Wood products & 1.1 & 0.6 & 0.2 & 0.1 & 0.3 \\
\hline Wood pulp products & 1.1 & 0.5 & 1.6 & 0.7 & 1.0 \\
\hline Textiles & 3.0 & 4.1 & 7.4 & 6.2 & 12.7 \\
\hline Machinery, mechanical appliances, base metals and electronic items & 76.9 & 76.3 & 70.8 & 82.4 & 68.9 \\
\hline Ceramic and melamine products & 0.7 & 0.6 & 0.1 & 0.1 & 0.1 \\
\hline Trekking equipment, footwear and carpets & 0.6 & 0.6 & 0.7 & 0.6 & 0.4 \\
\hline Miscellaneous manufactured articles & 1.5 & 1.8 & 1.3 & 0.9 & 0.9 \\
\hline Precious and semi-precious metals & 0.1 & 0.0 & 0.2 & 0.0 & 0.3 \\
\hline Tobacco and cigarettes & 0.2 & 0.3 & 0.2 & 0.0 & 0.0 \\
\hline Personal effects & 1.1 & 0.8 & 0.0 & 0.0 & 0.0 \\
\hline Total & 100 & 100 & 100 & 100 & 100 \\
\hline
\end{tabular}

Source: Department of Revenue and Customs. 
Table 33. Bhutan: Direction of Trade, 2001-2006

\begin{tabular}{|c|c|c|c|c|c|c|}
\hline & 2001 & 2002 & 2003 & 2004 & 2005 & 2006 \\
\hline & \multicolumn{6}{|c|}{ (In millions of U.S. dollars) } \\
\hline \multicolumn{7}{|l|}{ Exports } \\
\hline India & 100 & 106 & 71 & 171 & 226 & 320 \\
\hline Bangladesh & 5 & 5 & 5 & 9 & 13 & 10 \\
\hline Other & 2 & 2 & 1 & 2 & 19 & 84 \\
\hline Total & 105.8 & 113 & 77 & 183 & 258 & 414 \\
\hline \multicolumn{7}{|l|}{ Imports } \\
\hline India & 148 & 156 & 220 & 225 & 290 & 288 \\
\hline Japan & 13 & 7 & 4 & 13 & 15 & 9 \\
\hline Germany & 1 & 2 & 1 & 94 & 5 & 4 \\
\hline United States & 1 & 1 & 1 & 2 & 2 & 3 \\
\hline United Kingdom & 3 & 6 & 0 & 3 & 1 & 1 \\
\hline Singapore & 5 & 5 & 4 & 9 & 10 & 11 \\
\hline Thailand 1/ & 6 & 5 & 3 & 8 & 6 & 6 \\
\hline China 1/ & 0 & 2 & 1 & 5 & 4 & 6 \\
\hline Bangladesh 1/ & 1 & 1 & 1 & 4 & 3 & 2 \\
\hline Nepal $1 /$ & 0 & 0 & 0 & 1 & 2 & 4 \\
\hline Other & 11 & 11 & 12 & 48 & 48 & 86 \\
\hline \multirow[t]{2}{*}{ Total } & 191 & 197 & 248 & 411 & 386 & 420 \\
\hline & \multicolumn{6}{|c|}{ (In percent of total) } \\
\hline \multicolumn{7}{|l|}{ Exports } \\
\hline India & 94.1 & 93.8 & 92.6 & 93.8 & 87.6 & 77.2 \\
\hline Bangladesh & 4.5 & 4.0 & 6.2 & 5.0 & 4.9 & 2.5 \\
\hline Other & 1.4 & 2.2 & 1.1 & 1.2 & 7.5 & 20.3 \\
\hline Total & 100 & 100 & 100 & 100 & 100 & 100 \\
\hline \multicolumn{7}{|l|}{ Imports } \\
\hline India & 77.7 & 79.4 & 88.4 & 54.7 & 75.1 & 68.7 \\
\hline Japan & 6.9 & 3.4 & 1.7 & 3.2 & 3.8 & 2.1 \\
\hline Germany & 0.7 & 1.0 & 0.6 & 22.8 & 1.2 & 1.1 \\
\hline United States & 0.5 & 0.6 & 0.3 & 0.4 & 0.5 & 0.6 \\
\hline United Kingdom & 1.8 & 3.0 & 0.2 & 0.8 & 0.2 & 0.3 \\
\hline Singapore & 2.4 & 2.6 & 1.7 & 2.3 & 2.6 & 2.7 \\
\hline Thailand 1/ & 3.2 & 2.5 & 1.3 & 1.9 & 1.6 & 1.4 \\
\hline China 1/ & 0.2 & 0.8 & 0.3 & 1.1 & 1.1 & 1.5 \\
\hline Bangladesh 1/ & 0.7 & 0.8 & 0.4 & 1.0 & 0.9 & 0.4 \\
\hline Nepal 1/ & 0.2 & 0.2 & 0.2 & 0.3 & 0.6 & 0.9 \\
\hline Other & 5.6 & 5.8 & 4.8 & 11.6 & 12.4 & 20.4 \\
\hline Total & 100 & 100 & 100 & 100 & 100 & 100 \\
\hline
\end{tabular}

Source: Data provided by the Bhutanese authorities. 
Table 34. Bhutan: External Debt and Debt Service, 2001/02-2006/07 1/

\begin{tabular}{|c|c|c|c|c|c|c|}
\hline & $2001 / 02$ & $2002 / 03$ & $2003 / 04$ & $2004 / 05$ & $2005 / 06$ & $\frac{2006 / 07}{\text { Mar. }}$ \\
\hline & \multicolumn{6}{|c|}{ (In millions of U.S. dollars; end of period) } \\
\hline Total external public sector debt & 291.8 & 405.5 & 529.1 & 607.7 & 680.7 & 715.1 \\
\hline Convertible currency debt & 129.9 & 176.8 & 215.9 & 235.5 & 269.5 & 294.7 \\
\hline Concessional debt & 130 & 177 & 208 & 226 & 260 & 285 \\
\hline AsDB & 55 & 76 & 82 & 88 & 99 & 105 \\
\hline IDA & 33 & 42.9 & 53 & 59 & 70 & 78 \\
\hline IFAD & 14 & 20 & 20 & 20 & 21 & 22 \\
\hline Kuwait Fund & 5 & 3.6 & 2 & 1 & 1 & 1 \\
\hline Other $2 /$ & 23 & 35 & 51 & 58 & 69 & 79 \\
\hline Commercial debt & 0 & 0 & 8 & 10 & 9 & 9 \\
\hline Nonconvertible currency debt & 162 & 229 & 313 & 372 & 411 & 420 \\
\hline Debt service payments & 6.4 & 6.9 & 7.9 & 18.7 & 21.4 & 17.1 \\
\hline Convertible currency & 4.0 & 4.5 & 5.5 & 5.6 & 8.5 & 6.0 \\
\hline Principal & 2.7 & 2.9 & 3.0 & 2.6 & 4.4 & 2.4 \\
\hline Interest & 1.3 & 1.6 & 2.6 & 3.0 & 4.1 & 3.6 \\
\hline Nonconvertible currency & 2.4 & 2.4 & 2.4 & 13.1 & 13.0 & 11.1 \\
\hline Principal & 1.8 & 1.8 & 1.9 & 8.2 & 8.2 & 6.3 \\
\hline \multirow[t]{2}{*}{ Interest } & 0.6 & 0.5 & 0.5 & 4.9 & 4.8 & 4.8 \\
\hline & \multicolumn{6}{|c|}{ (In percent of GDP unless otherwise indicated) } \\
\hline \multicolumn{7}{|l|}{ Memorandum items: } \\
\hline External debt & 57.3 & 70.0 & 78.2 & 78.7 & 77.5 & $\ldots$ \\
\hline Convertible currency & 25.5 & 30.5 & 31.9 & 30.5 & 30.7 & $\ldots$ \\
\hline Concessional & 25.5 & 30.5 & 30.7 & 29.2 & 29.6 & $\ldots$ \\
\hline Commercial & 0.0 & 0.0 & 1.2 & 1.3 & 1.1 & $\ldots$ \\
\hline Nonconvertible currency & 31.8 & 39.5 & 46.3 & 48.2 & 46.8 & $\ldots$ \\
\hline Debt service ratio $3 /$ & 4.8 & 5.0 & 4.2 & 7.2 & 5.8 & $\ldots$ \\
\hline Nominal GDP (US\$ millions) & 509 & 579 & 677 & 772 & 879 & $\ldots$ \\
\hline Exports of goods and services (US\$ millions) & 133.0 & 137.7 & 188.9 & 258.4 & 372.9 & $\ldots$ \\
\hline
\end{tabular}

Source: Data provided by the Bhutanese authorities.

1/ Public and publicly guaranteed.

2/ Includes Australia, Austria, and Denmark.

$3 /$ In percent of exports of goods and nonfactor services. 
Table 35. Bhutan: External Debt and Debt Service by Creditor, 2001/02-2005/06

(In millions of U.S. dollars; end of period)

\begin{tabular}{|c|c|c|c|c|c|}
\hline & $2001 / 02$ & $2002 / 03$ & $2003 / 04$ & $2004 / 05$ & $2005 / 06$ \\
\hline \multicolumn{6}{|l|}{ Concessional debt } \\
\hline \multicolumn{6}{|l|}{ AsDB } \\
\hline Amount outstanding & 55 & 76 & 82 & 88 & 99 \\
\hline Interest payment & 0.5 & 0.6 & 0.7 & 0.8 & 1.1 \\
\hline Principal repayment & 0.6 & 0.7 & 0.9 & 1.0 & 1.3 \\
\hline \multicolumn{6}{|l|}{ IDA } \\
\hline Amount outstanding & 33 & 43 & 53 & 59 & 70 \\
\hline Interest payment & 0.2 & 0.3 & 0.4 & 0.6 & 0.6 \\
\hline Principal repayment & 0.2 & 0.3 & 0.4 & 0.6 & 1.7 \\
\hline \multicolumn{6}{|l|}{ IFAD } \\
\hline Amount outstanding & 14 & 20 & 20 & 20 & 21 \\
\hline Interest payment & 0.1 & 0.2 & 0.4 & 0.2 & 0.2 \\
\hline Principal repayment & 0.3 & 0.4 & 0.4 & 0.4 & 0.4 \\
\hline \multicolumn{6}{|l|}{ Kuwait Fund } \\
\hline Amount outstanding & 5 & 4 & 2 & 1 & 1 \\
\hline Interest payment & 0.4 & 0.1 & 0.1 & 0.1 & 0.0 \\
\hline Principal repayment & 1.5 & 1.5 & 1.2 & 0.6 & 0.4 \\
\hline \multicolumn{6}{|l|}{ Others } \\
\hline Amount outstanding & 23 & 35 & 51 & 58 & 69 \\
\hline Interest payment & 0.0 & 0.4 & 0.7 & 1.1 & 1.4 \\
\hline Principal repayment & 0.1 & 0.3 & 0.1 & 0.0 & 0.0 \\
\hline \multicolumn{6}{|l|}{ Total concessional debt } \\
\hline Amount & 130 & 177 & 208 & 226 & 260 \\
\hline Interest payment & 1.3 & 1.6 & 2.4 & 2.8 & 3.3 \\
\hline Principal repayment & 2.7 & 3.1 & 3.0 & 2.6 & 3.8 \\
\hline \multicolumn{6}{|l|}{ Commercial debt } \\
\hline Amount & 0 & 0 & 8 & 10 & 9 \\
\hline Interest payment & 0.0 & 0.0 & 0.2 & 0.3 & 0.8 \\
\hline Principal repayment & 0.0 & 0.0 & 0.0 & 0.0 & 0.6 \\
\hline \multicolumn{6}{|l|}{ Nonconvertible debt } \\
\hline Amount & 162 & 229 & 313 & 372 & 411 \\
\hline Interest payment & 0.6 & 0.5 & 0.5 & 4.9 & 4.8 \\
\hline Principal repayment & 1.8 & 1.8 & 1.9 & 6.1 & 6.1 \\
\hline \multicolumn{6}{|l|}{ Total debt } \\
\hline Amount & 292 & 405 & 529 & 608 & 681 \\
\hline Interest payment & 1.9 & 2.1 & 3.0 & 7.9 & 8.9 \\
\hline Principal repayment & 4.5 & 4.9 & 4.9 & 8.7 & 10.5 \\
\hline
\end{tabular}

Source: Data provided by the Bhutanese authorities. 